\title{
LA GUERRA DE MÉXICO*
}

Luis Manuel del Rivero

\section{Artículo I}

Los norteamericanos ocupan ya la hermosa México, orgullo del imperio español, la vez primera después de más de trescientos años de pacífica existencia profanada por la planta de bárbaro invasor. Cumplióse la profecía del gran demócrata americano Jefferson, que a fin del siglo [XVIII] predecía que antes de cincuenta años ondearía la constelación americana sobre las torres de la magnifica catedral de México, si bien probablemente se refería a otra conquista más pacífica, menos desastrosa y humillante para el genio de la libertad, no tan insegura y comprometida como la que han llevado a cabo las armas victoriosas del general Scott.

Para que este gran suceso se haya verificado, y fuese perdiendo la predicción el aire de balandronada patriótica que le daban las circunstancias, ha sido preciso que la revolución inaugurada en el mundo por la declaración de independencia de las colonias inglesas, y por la de los derechos del hombre hecha por la [Asamblea] Constituyente, continuando su carrera devastadora, minase todos los tronos, dícese por el pie, auxiliada de las pasiones y de las miserias humanas, la grandiosa fábrica del imperio marítimo español, asentada sobre las robustas bases del recíproco interés y de la justicia, y que atajando el vuelo magnífico de México, cuando más cerca se hallaba de la cumbre de una prosperidad serena, la derribase de un golpe en un lago de sangre

* Edición y notas de Raúl Figueroa Esquer. 


\section{LUIS MANUEL DEL RIVERO}

de hermanos para luego revolcarse en el cieno de los pronunciamientos, y por último venderse ignominiosamente a la merced de un orgulloso vencedor que se abre paso por entre ruinas e incendios.

¿Son éstos, oh libertad, tus beneficios? ¿Éstos los trofeos de tus victorias? ¿Éstas las lecciones que nos envías desde el nuevo mundo donde has fijado tu trono indestructible? ¿Éstos por fin los ejemplos de moderación que has logrado inspirar a tus adoradores, los hijos pacificos, inteligentes y laboriosos de Franklin y de Washington?

Lloremos la suerte de la ciudad infortunada, cuyos numerosos hijos no han sido [capaces] para defenderla de un puñado de bisoños aventureros; lloremos mil víctimas inocentes sacrificadas al furor de la guerra por la ambición de unos y por la impericia o abatimiento de otros; 1loremos el golpe que ha puesto fin a la vida más pura y patriótica de América, la del inmortal don Nicolás Bravo, ${ }^{1}$ valiente entre los valientes, héroe de la humanidad en la independencia, cuyos días han sido después un tejido de abnegación y sacrificios hechos en el altar de la patria; lloremos sobre todo la súbita decadencia de una nacionalidad que prometía tantos días de vigor y de pujanza.

iTriste cuadro que se presta a serias reflexiones y exige algunas 130 explicaciones!

El virreinato de México en trescientos años de pacífica existencia había alcanzado un grado tal de abundancia y prosperidad, que vive aún en la memoria de algunos que lo disfrutaron, y contrastando tan singularmente con las miserias y desgracias sobrevenidas, parece ya relegado al período fabuloso de la edad de oro de los pueblos. Sin la ostentación y bulla en su lugar, el orden público se mantenía por su propio peso sin el puntal de las bayonetas, por sólo la fuerza de la justicia y de la mutua conveniencia, por sólo el prestigio de la autoridad, objeto de un culto universal y religioso. No es posible idear un gobierno nì más sencillo, ni más económico, ni más acatado. Un virrey con sus comandantes y gobernadores de provincia sin el aparato y balumba

${ }^{1} \mathrm{La}$ información con la que contaba el autor estaba equivocada en este punto. Nicolás Bravo no murió, sino hasta 1854. 
de inmensas oficinas bastaban a lo militar y político; la Audiencia, colocada de intento por nuestros reyes en la eminencia de la región del poder, con sus alcaldes y corregidores proveía ampliamente a la justicia, primera necesidad social, y a las mil atenciones de la administración y gobierno de los pueblos. La Iglesia, en perfecta armonía con el Estado, satisfacía copiosamente a las necesidades espirituales, y formaba el lazo íntimo y secreto que unía a todas las clases.

Las arcas públicas se henchían anualmente con veinte millones de duros recaudados sin esfuerzo, principalmente en el ramo de tabacos que sobre un consumo de siete y medio millones dejaba cuatro líquidos, de las platas y azogues que prođucían sobre cuatro y medio millones, de las alcabalas que rendían tres, bulas 300,000 pesos, novenos 193,000 , subsidio, anatas y vacantes 167,000 , de la capitación de indios, mediante la cual estaban exentos de alcabalas y otras gabelas, que producía cosa de un millón. Los gastos de giro y recaudación no excedían de un 10\%. Los generales del virreinato fueron en 1802 como sigue:

Sueldos del virrey, intendentes y

empleados de Hacienda, Pts. ................................................ 510,000

Administración de justicia ................................................. 130,000

Pensiones y otras cargas comunes ..................................... 500,000

Situados ultramarinos de América y Asia ...................... 3,010,000

Tropas veteranas y milicias ......................................... 1,500,000

Presidios contra los indios bárbaros .............................. 1,100,000

Arsenal de San Blas ......................................................... 100,000

Fortificaciones y buques de guerra en Acapulco y

Veracruz ................................................................... 1, 100,000

Misiones de California y otras ...........................................50,000

Total de pesos .......................................................... 8,000,000

Así pues, México, después de proceder desahogadamente a todas sus atenciones y a las de otras posesiones de la Corona, dejaba disponible un cuantioso sobrante. 


\section{LUIS MANUEL DEL RIVERO}

La Iglesia se sostenía holgadamente de las obligaciones diarias, del rédito de un capital de cuarenta y cuatro millones y medio de pesos a que en 1807 se estimaba por un cálculo bajo e incompleto la riqueza acumulada en sus manos por la piedad de los fieles, capital impuesto a un módico interés sobre la propiedad territorial, rústica y urbana, del producto de sus fincas que no subían a tanto, y del diezmo.

Con todos estos gravámenes, la minería enviaba anualmente a la Casa de Moneda de México, por valor de 24 millones de pesos; la agricultura, sin el arbolado y la ganadería, producía un valor equivalente; la industria otro de seis millones aproximadamente; y Veracruz, en el apogeo de su prosperidad, en 1802, ponía en movimiento un valor de $60,445,955$ pesos de comercio legal, en el que no se incluían las importaciones y exportaciones hechas por cuenta de la Real Hacienda, y que se distribuían en esta forma:

Importación de España

En efectos nacionales $11,539,217$

En extranjeros $8,851,610$ $20,390,827$

Exportación para España $33,866,219$

Importación de América $1,607,729$

Exportación para América $4,581,148$

Así la abundancia, derramando con profusión sus dones en México, recompensaba ampliamente el trabajo, en el que no exigía otras condiciones que la aplicación y la honradez, y desterraba de la sociedad el pauperismo con sus cien plagas devoradoras. Reinaban con ella la buena fe y la confianza que eran el alma de las transacciones civiles, la unión de las clases, la cordialidad en las relaciones domésticas, la caballerosidad en el trato social. No son estas pinceladas de fantasía, sino rasgos característicos de una época dichosa, gravados profundamente en la memoria de los restos que aún viven de la generación que disfrutó de sus dulzuras. 
Era tanto más que admirar aquel concierto cuanto más dificil se hacía mantener el necesario equilibrio entre los heterogéneos elementos de una población de 6 a 7 millones de almas; problema que siempre se propuso la administración española y que trató de resolver con celo y con pureza. Por eso restringió siempre la introducción de negros en México, en que sólo se encontraron diez mil a la época de la emancipación. La clase realmente desvalida, sobre la que descargaba el peso material de la labranza y minería, y que formaba la gran masa de la población, era la de los indios, que tantos y tan incesantes desvelos mereció a nuestro legislador desde que Isabel la Católica la distinguió con su particular afecto; clase salvada de la total ruina que ha cabido en suerte a las tribus que han estado en contacto con los norteamericanos, y cuya situación mejoraba continuamente en nuestras manos, gracias a esa ilustrada protección de nuestras leyes y de nuestros magistrados, y a la no menos decidida de la Iglesia. La inmigración constante de españoles llevaba al seno de aquella sociedad la nueva sangre que la rejuvenecía y vigorizaba. La falta de este elemento no reemplazada de modo alguno, es una de las causas más positivas de la retrogradación de aquella sociedad. Los criollos en fin, eran considerados por nuestras leyes y nuestro gobierno a la par de los españoles en sus derechos y en la provisión de los empleos, pudiendo optar a todo en España y en América, excepto los mandos superiores en su tierra.

El Español, 9 de noviembre de 1847.

\section{Artículo II}

Para completar el sumario de los bienes mortuorios de nuestro antiguo régimen americano, necesitamos hacernos cargo de la enseñanza, que de manera alguna se hallaba desatendida por nuestro gobierno, sino más bien colocada allí a una altura a que no había llegado en la metrópoli. Una universidad, numerosos seminarios y colegios, entre otros el famoso de la Minería, multitud de escuelas, difundían gratuitamente 
la enseñanza profesional, secundaria y primaria, de que participaban abundantemente todas las clases de la sociedad, aun la de los indios, que no sólo podían instruirse, sino aspirar a todas las profesiones, y aun al mismo sacerdocio.

Al detenernos en esta rápida consideración de las bases y resultados de nuestro sistema colonial, no ha sido nuestro ánimo extasiarnos en su contemplación como en una obra acabada y perfecta: sabemos que los gobiernos no tienen más que un mérito relativo, el de apropiarse a las circunstancias y condiciones de la sociabilidad de un pueblo, que ellos no son un fin, sino un medio de hacerle avanzar en la senda de su peculiar destino, y que cuando rebeldes a su misión se convierten en obstáculo insuperable, están condenados a ver fenecer dentro de sí el principio vital que los animaba.

Importábamos empero considerar ese sistema por dos razones: primera y principal, porque él es el punto de partida, desde el cual se ha lanzado la revolución mexicana en un oscuro porvenir; segunda y accesoria, por presentar de bulto la verdad de que España acertó en el gobierno de sus colonias, las cuales nunca hubieran podido llegar a la posesión en una existencia tan tranquila, tan holgada y feliz, bajo un

134 gobierno que contrariase su peculiar constitución y destino. Nosotros no titubeamos en abandonar nuestro sistema a la prueba de este criterio, el más razonable en política como en moral, el de juzgar el árbol por sus frutos; $y$ en que se pongan en paralelo con las nuestras las colonias inglesas, las francesas, o las de cualquier otra nación al tiempo de su emancipación; que se cotejen sus orígenes y sus historias respectivas; nuestra legislación de Indias, sencilla y uniforme con el Monitor argelino o las actas del parlamento imperial; nuestro Consejo de Indias, con sus compañías y gobiernos; nuestros magistrados, obispos y misioneros, con los suyos; nuestra esclavitud; nuestra organización del trabajo en el continente y la parte que dimos a los indios en nuestra civilización, con lo que ellos han hecho y están haciendo en esta línea. Y si al mismo tiempo comparamos con los resultados obtenidos los medios de que unos y otros nos hemos servido; la espontaneidad con que han nacido y crecido nuestras colonias, con la violencia que lo 
han hecho las suyas; esos ejércitos y armadas que los pueblos modernos en el apogeo de su grandeza envían a fundarlas y mantenerlas con las carabelas y bergantines que condujeron a nuestros Colones, Corteses y Pizarros; esos establecimientos, en fin, que pesan de una manera tan insoportable como Argel y la India sobre sus metrópolis, con los nuestros que desde un principio no sólo se han bastado a sí mismos, sino que nos han auxiliado y continúan auxiliándonos enérgicamente; cuando todo esto miramos y consideramos, sentimos rebosar en nuestro pecho un orgulloso españolismo, que nos redime de mil humillaciones presentes.

Pero si ese sistema, adecuado a las circunstancias y elementos de nuestras colonias, bastaba a su gobierno del momento, no prevenía el del porvenir; de aquí, que ellas a la emancipación se encontraron con el gobierno sobre sus brazos, sin experiencia ni educación previa: de aquí, que el paso del antiguo al nuevo orden de cosas se verificó por un salto, sin transición natural de ningún género: de aquí que el nuevo orden de cosas no ha podido plantearse, y que la sociedad se muere allí en el lecho de la anarquía.

Por nuestra parte aceptamos el cargo con explicaciones; pero pedimos que cada cual lo acepte, y con él las consecuencias desastrosas de la emancipación. Cierto es que nuestro gobierno no dio educación política a sus pueblos de América como no la dio a los de la península, ni más participación en los negocios comunes, que la escasa ejercida en los ayuntamientos y consulados. Nuestro gobierno en América estuvo basado sobre la eliminación del pueblo en las regiones del poder, sin dejar por eso de ser tan ilustrado, tan justo, religioso y humano como sea dable a uno de esta especie.

Pero es mucho exigir de la naturaleza humana, que un gobierno, al fin compuesto de personas y de intereses, haya de renunciar a sus pasiones, y de llevar sus previsiones hasta el límite de su transformación posible, y más allá de las condiciones de su actual existencia. ¿Quis est hic? ${ }^{2}$ Con todo, aún es una gloria nuestra el que un ministro

${ }^{2}$ ¿Quién es éste? 


\section{LUIS MANUEL DEL RIVERO}

español se levantase a esa altura de previsora abnegación, y propusiese, como un remedio a la política desastrosa del pacto de familia, la política nacional del establecimiento de monarquías borbónicas en América, y que este ilustrado proyecto se hiciese oír en los consejos de nuestros reyes, años antes de la revolución francesa. ${ }^{3}$

Por otra parte, la composición de nuestra población americana y su dispersión por un territorio inmenso, hacían poco menos que imposible la adquisición de costumbres políticas, que además no estaban por el momento ni en nuestras ideas ni en nuestras tradiciones. ¿A quién en tales circunstancias debía investir nuestro legislador con derechos políticos? ¿Por ventura a la inmensa mole de la población indígena? Pero aún no se había pervertido su buen juicio, como lo fue más tarde, por la Declaración de los Derechos del Hombre. ¿Acaso a los pocos españoles, dispersos aquí y allá, luchando con los obstáculos de un trabajo de gigantes? Pero estos españoles y sus hijos tenían harto que hacer con proveer al sustento común, a las necesidades de la agricultura, de la minería y del comercio, sin echarse el sobrepeso del gobierno, que por otro lado veían en manos respetables.

En muy otras circunstancias se vieron las colonias inglesas de 136 Norteamérica. En primer lugar dominaba en ellas el elemento inglés, y puritano por añadidura; el cual no necesitaba de estímulos de fuerza para desarrollarse, como lo hizo aún a pesar de su gobierno, según sus condiciones naturales de publicidad, espíritu de asociación, juicio por jurados y libertad de conciencia. Su población era además europea, y no tenía para marchar la rémora de una inmensa población indígena, porque la raza anglosajona ha tenido y tiene por más cómodo y expeditivo exterminar a ahuyentar delante de las tribus indígenas, que servirse de ellas aun como esclavos. Por último, esa población era más compacta, toda vez que el terreno lo fue ocupando según sus necesidades, no de un golpe como nosotros.

${ }^{3}$ El autor se refiere al proyecto del conde de Aranda de transformar a Carlos III en emperador y que algunos de sus hijos se ocupasen de la dirección de diversos reinos en América. 
De todos modos, eso es lo que hicimos y en ese estado dejamos a nuestras colonias. Mientras el espíritu moderno se fue infiltrando pacíficamente en nuestras leyes y costumbres durante los reinados de los primeros Borbones, América participó más que la península de este progreso; pero desde que llamando a la puerta de los gobiernos con la violencia de la revolución francesa, hizo a éstos recoger velas en el rumbo de las reformas, y mantenerse a la capa para dejar pasar la tormenta, el progreso se interrumpió entre ellos, aunque mucho menos que entre nosotros. ¿Cuál es, pues nuestra culpa, si apoderándose del mundo un día de vértigo revolucionario las cabezas exaltadas de aquí y de allá, se dieron tanta prisa a demoler el edificio antiguo, creyendo buenamente que poseían una vara mágica para hacer brotar del suelo otro nuevo tan cómodo como grandioso? La culpa es más bien de la época, y muy señaladamente de la América, que locamente trocó una felicidad real por otra fantástica, y de la Europa que fue su cómplice en esta obra de iniquidad.

Si no se hubiera forzado el curso natural de las cosas, y no se nos hubiese impuesto el progreso a cañonazos, España penetrada del espíritu moderno, y cuya misión no había concluido en América, habría llevado de la mano, y gradualmente a sus colonias hasta el punto de sazón de una emancipación completa. Pero en fin no se hizo así, y cada cual debe cargar con su pecado. Examinemos ya la obra de la revolución.

El Español, 10 de noviembre de 1847.

\section{Artículo III}

Dice un célebre publicista-poeta, que jamás ha aparecido en el mundo una erupción de verdades sociales, igual a las que derramó la Asamblea Constituyente. Simpatizando nosotros en general con esas verdades, tan sólo objetamos la forma volcánica de su aparición y difusión, 
porque ni el espíritu humano recibe con tal premura las ideas, ni la sociedad acepta las reformas sino de una manera lenta y progresiva.

Pudiera pasar como programa del porvenir, mas como inmediata tarea de gobierno excedía el trabajo de muchas generaciones, según lo ha comprobado una dolorosa experiencia.

De todos modos, las ideas de 1789 cautivando despóticamente la opinión, se hicieron al momento gobierno, o más bien revolución. Al primer entusiasmo siguió, empero, la resistencia de los numerosos intereses conculcados, el grupo agudo de una sociedad lastimada por un experimento tan sensible como glorioso. Por toda contestación la revolución suprime las oposiciones, suprime los parlamentos, la nobleza, el clero, el mismo trono ... y en el delirio de su omnipotencia, no pudiendo sufrir aún los quejidos de las víctimas, pone en tortura al ingenio para discurrir más expeditos medios de destrucción, decreta el exterminio de ciudades y de provincias. ¡Jamás se vio sobre la tierra tan monstruosa mezcla de barbarie y civilización, ni una más hermosa causa defendida por una serie igual de negros crímenes y espantosas catástrofes!

Perdidos los primeros bríos, que a tanta costa rechazan la invasión extranjera, la revolución abjura sus feroces instintos, se domestica; pero la corrupción que sobreviene relaja todos los resortes, disuelve todos los vínculos, y la sociedad fatigada y sin fe se arroja en brazos de un soldado victorioso.

Bonaparte comprende admirablemente su misión, y satisfaciendo el hambre y sed de gobierno que la sociedad experimenta, se constituye dentro y fuera en el legítimo representante de los principios más puros de la revolución, de aquí sus nobles triunfos y sus más legítimos títulos a la inmortalidad. Pero llegado a aquella altura en que las cabezas humanas se desvanecen, soltadas las bridas a su ambición fogosa, comenzóse a despeñar Napoleón comprometiendo gravísimamente en su catástrofe la causa de esa misma revolución, por la que había desempeñado un papel en el mundo. Mientras una gran nación y todo un nuevo orden de cosas recogían el fruto de sus trabajos y de sus victorias, su brazo fue invencible; pero principia a enflaquecerse tan 


\section{LA GUERRA DE MÉXICO}

luego como la terrible cuenta de sangre de oro y de libertad que la Francia tenía abierta a la guerra, hubo de saldarse con reinos y ducados arrojados a la insaciable avaricia de una fastuosa corte imperial.

¿Quién dijera que la pobre y vilipendiada España fuese el humilde pastor elegido para derribar a este moderno gigante! ¿Quién, que la ingratitud había de ser colosal como el beneficio!

España, sólo atenta a su honra y sin contar más que con su valor, se arrojó en la más completa desnudez de recursos y en medio de las circunstancias más apremiantes a la más noble y gloriosa temeridad que jamás haya intentado un pueblo en defensa de su independencia. Esta extraordinaria decisión que debía variar los destinos de Europa, produjo entre nosotros la fusión en un inmenso patriotismo de todos los intereses y de todas las opiniones a la sazón tan divergentes. También figuraban en las filas de la patria los liberales, representantes de las ideas de 89 , que sin haber hecho mucho camino en la opinión, dominaban las eminencias de la licencia y de la literatura, y contaban con el apoyo de una juventud generosa, debiendo esta vez volverse contra su mismo origen, y concurrir a rechazar la invasión francesa, y que se dirigía a entronizarlas en la persona del culto y pacífico José.

Mas el pueblo español que no se levantaba por la libertad, mucho menos por una libertad a la francesa, que aún hoy en día no comprende, no hizo alto en esas ideas y dando la cara a la Francia, sólo ocupado en mantener una lucha de gigantes, dejó a las espaldas a sus sabios legisladores, quienes tan buena maña se dieran, que en breve la venerable monarquía de los Alfonsos y Fernandos se mostró al mundo regenerada en las aguas del pacto social, aunque sin haber pasado por las horcas caudinas de un juego de pelota, ni de un 10 de agosto.

Este anacronismo político que todavía estamos pagando, nos costó por de pronto la pérdida de nuestras Américas, cuya dominación era incompatible con el desarrollo lógico del principio de la soberanía nacional proclamado por las Cortes generales y extraordinarias de Cádiz, con el beneficio de la representación nacional que entre otros les había conferido la junta central, y con el sistema en fin de publicidad 
y de libertad, tal cual prevaleció, aplicado injusta y sin ninguna modificación al gobierno de las colonias.

Cuando en el verano de 1808 empezaron a conocerse en México los graves acontecimientos de la Península, verificóse la misma explosión de patriótica indignación que en ésta, igual resolución de desconocer las abdicaciones de Bayona, de rechazar el gobierno de Murat, y de acatar y auxiliar un gobierno legítimo nacional. Sin embargo, a la llegada de las noticias del levantamiento y formación de juntas, empezó a deslizarse en los ánimos la idea de la independencia a la sombra de la tentación poderosa de no ser menos que las provincias de la metrópoli, y de erigirse en junta soberana que conservase tan vastos dominios al rey Fernando, cuando quiera que saliese de la cautividad francesa. El ayuntamiento de México dominado por el ascendiente de su procurador síndico, a la sazón un abogado americano, se hizo el eco inocente de esta opinión, y asumiendo la representación y voz de todo el país, se dirigió al virrey Iturrigaray en solicitud de una junta donde se regenerasen todas las autoridades, y que ejerciese la soberanía en la orfandad del poder real. Pero el real acuerdo a quien consultó el virrey, desaconsejó tan trascendental medida, opinando

140 que las circunstancias no eran extremas como en la península, que nada había hasta el momento que no estuviese previsto en la legislación de Indias, y que mientras se organizaba un gobierno nacional en aquella, continuasen las cosas en el mismo estado, viendo sólo riesgos inminentes en la política que proponía el ayuntamiento.

Éste, empero, no se dio por batido, y volviendo de nuevo a la carga, al fin atrajo de nuevo a su partido al virrey, quien a pesar de haberse conformado primero con el sesudo dictamen del Acuerdo, al fin, atropellando por su resistencia y sus enérgicas protestas contra el acto, reunió una junta magna de autoridades eclesiásticas, militares y civiles del ayuntamiento y varios particulares, en la que después de acalorados debates, se acabó por aclamar a Fernando y no reconocer más gobierno que el que por él o sus legítimos pretendientes se formase en la metrópoli, declarando que entretanto continuaba la autoridad del virrey, tribunales y autoridades. Habían estado, pues, en presencia el contrato 
social defendido por el ayuntamiento y sus abogados, y el derecho divino, o más bien nuestra antigua jurisprudencia nacional, bajo cuyos auspicios subsistían las colonias, que fue defendida con vigor por los fiscales del Acuerdo y otras autoridades ilustradas. Sin embargo, la balanza allá como acá, se inclinaba por entonces del lado del primer sistema, en el cual, cada vez más obcecado, a pesar de sus más rectas intenciones, dio el virrey un nuevo paso, que fue la convocación de un congreso general, compuesto de los diputados de todos los ayuntamientos del reino, gran desiderátum por el momento de los amantes de la independencia mexicana.

Por entonces llegaron los comisionados de la Junta Soberana de Sevilla, demandando la obediencia de México, y pliegos de la de Oviedo, pidiendo la cooperación y auxilio de aquel reino para la grande empresa en que la nación se hallaba embarazada. El partido del ayuntamiento tomó con esto nuevos bríos, y a vista del fraccionamiento del poder soberano, insistió más y más en que éste había [re]caído en el pueblo, y que México debía usarlo como lo usaban las provincias de España.

Alarmado grandemente con tales progresos el partido español, porque ya había partidos en México, sintiéndose dueño de una fuerza inmensa, determinó atajar al torrente sus avenidas, y una noche de septiembre del mismo año depuso al virrey, y le remitió a España, procediendo enseguida en justicia contra los fautores de sus planes. Tal fue esta medida ruidosa, vituperable en las formas, pero que había hecho necesaria el curso de los sucesos, si México había de continuar siendo colonia española. Los ánimos quedaron agriados, y el partido vencido dispuesto a echar mano de la primera coyuntura favorable.

Sucedió a poco el débil gobierno del virrey-arzobispo [Francisco Javier de Lizana y Baumont], y luego el más rígido del real Acuerdo, bajo los cuales no se tranquilizaron los ánimos, antes echaban leña a la intestina discordia las noticias que de la metrópoli llegaban, y los nuevos principios de gobierno que en ella se proclamaban, hasta que en fin estalló la rebelión abierta en Dolores el 16 de septiembre de 1810 , casi al tiempo que el virrey Venegas destinado a combatirla, desembarcaba en Veracruz. 
El cura Hidalgo, no conocido por ningún antecedente honroso, fue quien lanzó el primer grito de la rebelión, cuya causa, engrosándose súbitamente con turbas inmensas de indios y gente perdida, apenas regimentada por algunos militares, vino toda cubierta de sangre inocente, de robos y de incendios a estrellarse en el Monte de las Cruces casi a la vista de México, en Aculco, en Guanajuato y en el puente de Calderón. Dispersadas aquí las turbas, el mismo caudillo en fuga, y luego preso y ajusticiado, pulularon los facciosos en el país, hasta que nuevos jefes, que a su vez sucumbieron la organización descollaba entre ellos, el famoso cura Morelos, vaquero hasta la edad de 32 años, a cuyo tiempo se puso a aprender latín, que más tarde cambió por un machete, poniéndose al frente de la rebelión del Sur, bajo el humilde título de siervo de la nación, y siendo en fin, cogido y fusilado, en fin de $1812 .^{4}$

La insurrección trató de organizarse formando varias juntas soberanas, varios congresos y proyectos de Constitución más o menos fielmente calcados sobre la nuestra, todo de efímera existencia; pero es de advertir que ella no proclamó abiertamente la independencia, hasta el 6 de noviembre de 1813, que lo fue por el Congreso Supremo

142 de Chilpancingo, y que los primeros jefes que la dirigieron tenían cuidado de no omitir entre sus gritos el de viva Fernando, si no querían ver desiertas sus filas. Esta idea de aue la guerra tenía por objeto conservar aquellos dominios para su rey legítimo contra la traición del gobierno de México que quería entregarlos a Napoleón, fue la palanca principal en manos de aquellos jefes para remover las masas. Los otros gritos del sanguinario Hidalgo eran: ¡Viva la nación!, ¡Viva la religión!, ¡Mueran los gachupines!

Esta guerra fratricida y bárbara que recibió sus más fuertes golpes de manos del enérgico y activo general Calleja, tanto cuando mandaba divisiones, como cuando estuvo al frente del gobierno hasta 1816 estuvo sostenida del lado de la insurrección por clérigos, militares y

${ }^{4}$ Rivero comete una imprecisión. Morelos fúe fusilado el 22 de diciembre de 1815. 
abogados más o menos ilustrados y respetables que estaban en minoría en sus respectivas clases, aunque el deseo de la emancipación fuese bastante general, y que prevaliéndose de las circunstancias favorables de la época, había desplegado la bandera de la rebelión ocultando al príncipe sus designios de independencia bajo el pretexto de amor a Fernando, hasta que vieron al pueblo bajo que llenaba sus filas, suficientemente avezado a la licencia para poder sin riesgo proclamar en su presencia otros votos más íntimos. Por el lado del gobierno se encontraba la gran masa de intereses y de personas sensatas o ilustradas del país, que si bien en el fondo de su corazón anhelaban la emancipación, no la querían por medio de los horrores de una tan bárbara guerra civil, ni en unas manos, en lo general tan soeces y manchadas de sangre inocente como las que por ella luchaban. Así es que todo el que tenía que perder fuese criollo o español, todo el que podía discurrir con pocas excepciones, era amigo y sostenedor del gobierno. El número de voluntarios, en que figuraban españoles y criollos, y que hacían una guerra activa y de las más atroces, era inmenso; las tropas veteranas eran comparativamente en muy escaso número, y aún en ellas figuraban por la mayor parte los soldados del país, sobre todo hasta 1812 en que se enviaron allá algunas tropas españolas. Los recursos pecuniarios para sostener estas grandes fuerzas que no pueden estimarse en menos de 80,000 hombres, todos salían de los fondos del erario y de los inmensos donativos de los particulares que rivalizaban en generoso desprendimiento.

Si a pesar de esto se prolongó la guerra, atribúyase al favor de la época, al estímulo que recibía de toda parte, incluso España; a las circunstancias físicas del país, y lo atrasado del bajo pueblo tan susceptible de recibir inspiraciones ajenas, sobre todo de sus curas y otras personas acostumbradas a mandarle. Pero a pesar de todo, México triunfó de la insurrección casi por sus solos recursos y el virrey Apodaca, auxiliado de Iturbide, Cruz, Negrete y otros generales, tuvo la gloria de ser el pacificador de la Nueva España, hasta el punto de no existir más que unas gavillas errantes en las montañas del Sur, al mando 
LUIS MANUEL DEL RIVERO

del cabecilla Guerrero en 1820, época en la cual se trastornaron los destinos de México, merced a otras causas que expondremos.

El Español, 12 de noviembre de 1847.

\section{Artículo IV}

Hay épocas de seducción en que apenas puede mantenerse la conciencia más firme. Fascinado entonces el espíritu público, no sufre discusión y es llevado por el impulso mágico de ciertas palabras sacramentales.

El año de 1820 era una de estas épocas en España y en América, y la palabra mágica en que se cifraba la suma del poder y de la ventura, era la palabra "libertad", que encerraba todo un sistema político aún no ensayado debidamente, y engalanado además con los honores del martirio. La primera de las virtudes militares sucumbió a esta terrible prueba en el ejército de la isla de León, el cual, merced a tan deslumbrador influjo, pudo separarse de la línea de su deber, y volver sus bayonetas contra el soberano que se las ponía en sus manos para mantener ileso el cetro de Castilla más allá del Atlántico, y aún pudo haciendo esto mecerse en la extraña ilusión de que servía a los más grandes intereses de su patria.

México, que para mantenerse en la devoción de la metrópoli, sólo necesitaba de este refuerzo en el supuesto de trastornarse de nuevo los destinos políticos de ésta, se hallaba sujeto a influencias, habiendo germinado tanto más en la lozana imaginación de aquellos naturales las abundantes semillas de la libertad derramadas por la imprenta libre durante el primer período constitucional, cuanto que la libertad era para ellos fiadora segura de su independencia. Así que recibieron con entusiasmo la proclamación de la nueva era liberal, volviéndose a encender con ella la mal apagada hoguera de la discordia, merced a una imprenta libre que venía a desgarrar las llagas recientes de una horrorosa guerra civil de diez años. Entre los españoles, si bien unidos en el sentimiento de fidelidad a la metrópoli, habia quienes de buena 
fe simpatizaban con el movimiento liberal, y deseaban verlo triunfante. El ejército mismo, firme en su decisión y en su lealtad, contaba con jefes y oficiales liberales que igualmente que la conservación de aquel rico imperio, deseaban consagrarse a la defensa de la libertad. Se hacía, pues punto menos que imposible la continuación del antiguo orden de cosas; la avenida de nuevas ideas inconciliables con él, minaban por su base la dominación española en América, y era en vano volver los ojos a la metrópoli, porque de allí precisamente partía la causa del mal y del desorden.

En este conflicto se fraguó un plan de contrarrevolución en México, que la voz pública atribuyó al mismo virrey Apodaca, quien se ha dicho después, obraba por expreso mandato de Fernando VII. Este plan que tenía por objeto la proclamación del rey absoluto, y en su caso la separación completa de la metrópoli bajo el mismo rey Fernando, en caso de que la revolución le despojase del trono de Castilla, o de un príncipe de su familia en su defecto, se fraguó en la Profesa, casa de clérigos felipenses de mucho crédito en la capital, donde parece se reunían con el virrey el auditor Bataller, uno de los magistrados más probos y entendidos de aquella audiencia, y los doctores Monteagudo y Tirado, individuos de la misma casa, español el primero y americano el segundo. Contóse para llevarle a cabo con alguno que otro general, recayendo, en fin, la elección en Iturbide, que a su cualidad de americano unía la de una gran reputación militar, y la de ser hombre de acción y de intriga. El proceso que se le había promovido por desafueros y violencias de que le acusaban, cometidas durante su mando en el Bajío, se acercó por entonces.

Las revoluciones y las contrarrevoluciones pertenecen a ese círculo vicioso de fuerza y de anarquía, de que no es posible resulte jamás el orden social, que sólo existe en el crédito y acatada dominación de las ideas morales. La contrarrevolución en México pecó, pues, contra estos sagrados principios de deber y de alta moralidad, que son la única salvaguardia del orden en las cosas humanas; pero tenía en su excusa la más profunda convicción y la intención más patriótica, si cabe excusa en la postergación del deber; único faro seguro de la 


\section{LUIS MANUEL DEL RIVERO}

conducta pública y privada, cualquiera que sean las consecuencias, que todas se las hecha sobre sí la Providencia, a cuyo cargo están los destinos de la sociedad y del hombre.

Pero la contrarrevolución se enredó en sus propias redes. El general Iturbide aceptó el cargo de jefe que se le conferia con la segunda intención de explotarlo en provecho propio y de su patria. ${ }^{5}$ Fiel hasta allí a la causa de la metrópoli, a la que había hecho señalados servicios durante la guerra de la insurrección, se encontraba probablemente agriado por un largo proceso que le habían atraído sus demasías, y por otra parte su gran perspectiva en su carrera militar, que a la edad de 37 años en que se hallaba, había ya casi recorrido; cuando por el contrario la revolución abrió un campo indefinido a su ambición. No tenemos fundamentos para privar a su decisión del mérito de haber sido también influida por el deseo de concurrir a la emancipación de su patria; objeto el más legítimo, si se hubiera perseguido con medios nobles.

Salió, pues, de México el 16 de noviembre de 1820, a la cabeza de una división de 2,000 hombres, y una conducta de 800,000 pesos, que una casa española bien conocida en México remitía a Manila por Acapulco, y que era en realidad la caja de la contrarrevolución que esa

146 misma casa ponía a su disposición, y de que usó Iturbide, si bien más tarde el gobierno mexicano reconoció y pagó esa suma. Iba también Iturbide con el fin aparente de batir los últimos restos de la insurrección que vagaban a las órdenes del cabecilla Guerrero en las fragosidades de la costa del Sur. Mas no bien había emprendido contra él algunas inútiles operaciones, cuando poniéndose ambos de acuerdo dio en fin el grito de independencia en Iguala el 24 de febrero de 1821.

Este Plan de Iguala, de cuyo pensamiento y redacción se jacta Iturbide en su Memoria de Liorna, ${ }^{6}$ no era en realidad sino el primitivo

${ }^{5}$ Para 1820 , Iturbide había alcanzado el grado de coronel del ejército realista. Al ser nombrado comandante del Ejército del Sur por el virrey Ruiz de Apodaca, Iturbide obtuvo el grado de general brigadier.

${ }^{6}$ Rivero se refiere al escrito titulado Manifiesto de Liorna. Juan de Dios Arias afirma: "Alli en Liorna fue donde Iturbide escribió su célebra manifiesto, 
de la Profesa, retocado y añadido en su parte liberal por un abogado de mucha reputación e influencia en la capital, el licenciado [Juan José] Espinosa de los Monteros, que sin embargo de haber sido frecuentemente el mentor de la revolución, ha huido en cuanto le ha sido dable de la agitación de la vida pública. Por él se garantizaban la religión católica apostólica romana, la independencia y el gobierno monárquico-moderado de Nueva España. Eran llamados a la sucesión de la corona Fernando VII, don Carlos, don Francisco, el archiduque Carlos, etc. Organizábase una junta de gobierno hasta las próximas Cortes constituyentes: garantizábanse propiedades, empleos, fueros y privilegios de la Iglesia; y se creaba el ejército trigarante, o de las tres garantías, a saber, religión, independencia bajo un gobierno constitucional, y unión íntima entre americanos y europeos.

La concepción era excelente, $\mathrm{y}$ ejecutada de buena fe, habría traído probablemente buenos resultados; pero por los mismos actores principales, y señaladamente por Iturbide nunca se consideró más que como un medio diplomático de suavizar las resistencias, y de llegar a mayores cosas. La conciencia y el criterio político de estos personajes variaban y han seguido variando hasta hoy con los sucesos de cada día, al único compás de sus ambiciones personales y de sus mezquinas pasiones. Dificilmente en la historia de ninguna revolución se encontrarían hombres ni partidos más desprovistos de sentido político.

Los soldados de Iturbide, una vez descubierto el secreto de su jefe, hubieron de vacilar un momento entre él y el gobierno: la revolución abandonada a sí misma, hubiera perecido en su cuna, si el virrey en vez de reducirse a desaprobar la conducta de Iturbide y a mantener inactivo un cuerpo de seis mil hombres en las inmediaciones de México, hubiera volado al peligro; pero cobrando vida con esta inacción, empezaron a llegar las adhesiones así del país, como del ejército, fas-

con fecha 27 de septiembre [de 1823], segundo aniversario de su entrada en México; ese notable documento no pudo publicarse en Toscana, sino en Londres, por Quin, amigo de Iturbide, precedido de algunas consideraciones." México a través de los siglos, 1972, México, Cumbre, IV, 104. 


\section{LUIS MANUEL DEL RIVERO}

cinados todos con esta monarquía borbónica que se aceptaba como una verdad; bien que sólo fuese un ardid destinado a servir de pasaporte a esa revolución.

Difundióse esto, pues, rápidamente y sin esfuerzo por el Bajío, Guadalajara, Querétaro y Puebla, y amagó a la misma capital, de cuyos fuertes fue rechazada y batida en Azcapotzalco por el nuevo virrey [Francisco] Novella, que había sucedido a Apodaca, depuesto y remitido a España, por el que podemos llamar partido liberal español.

Llega en esto el virrey O'Donojú, ${ }^{7}$ en cuyo nombramiento tanta parte tuvieron los diputados mexicanos en Madrid, alguno de los cuales ha hecho méritos después públicamente de los grandes servicios que prestó en aquel puesto a la causa de la independencia de su patria. Este desgraciado virrey, que tuvo la triste gloria de cerrar la respetable lista de jefes de aquella colonia que empiezan en Hernán Cortés, y que estaba destinado a morir tan pronto después de un gran festín, firmó el 24 de agosto los tratados de Córdoba que sancionaban la obra de Iguala, y abrieron a Iturbide las puertas de la capital, donde hizo su entrada triunfal a la cabeza del ejército trigarante el 27 de septiembre de 1821. Los restos dispersos del ejército español, víctima de

148 la intriga de los revolucionarios y de la perfidia de muchos de sus jefes, en actitud amenazadora, contrastaban con el júbilo general y quitaban el sueño al triunfador; pero fueron desarmándose, aunque no sin sellar aún su lealtad con lo más puro de su sangre, cual sucedió al regimiento de órdenes de Juchi.

Dueño Iturbide del mando supremo, gobernó, primero con la junta provisional y luego con un congreso que convocó, y en el que se desarrolló fuertemente la oposición republicana, nacida con su misma elevación y fortuna. El partido borbonista en que se habia refundido la porción del español que tomó parte activa en el Plan de Iguala, viéndose ya claramente burlado y defraudado de su objeto predilecto, la monarquía borbónica, por la ambición creciente de su héroe, y por

${ }^{7}$ Juan O'Donojú nunca recibió el nombramiento de virrey, sino el de Jefe Superior Político de la Nueva España. 
la declaración hecha de las Cortes de España, que anularon el 22 de febrero así el plan aquél como los Tratados de Córdoba, engrosó las filas de esta recia oposición, y contribuyó poderosamente a la caída del gobierno.

Sosteniase éste puramente por la facción iturbidista, habiendo llegado a tanto la nulidad política en su jefe, que ni supo crearse un partido nacional por medio de las reformas que exigía la situación, ni ejercer con rigor el mando para al menos imponer a sus numerosos enemigos. Parecía desvelarle tan sólo el propio engrandecimiento, que al fin después de varias tentativas realizaron sus partidarios, aclamándole Agustin $I^{8}$ en medio de un motín de soldados y de léperos la noche del 18 al 19 de marzo de 1822.

La comedia de la modestia del nuevo Washington, luchando con el perentorio llamamiento de la patria, se desempeñó admirablemente; pero Iturbide tuvo al fin que ceder y hacer este nuevo sacrificio de aceptar la corona imperial, no sin haberse resistido hasta lo último, no sin haber subido tres veces a la tribuna del Congreso para apoyar la proposición de aplazar este grave negocio, para cuya decisión no se reconocían con poderes algunos diputados. Es de advertir que por entonces aún era desconocida en México la resolución de las Cortes españolas.

La oposición del Congreso, sorprendido y violentado por una turba popular, creció con este suceso, y siéndole imposible al nuevo emperador gobernar con él, tuvo que apelar a un golpe de Estado, el disolverlo en 31 de octubre de 1822, reemplazándole con una Junta Constituyente, mucho menos numerosa, en que se prometía no encontrar tanta resistencia.

La disolución fue la señal de la revolución. El partido republicano levantó su bandera de rebelión en Veracruz, a la voz del comandante general de aquella plaza, don Antonio López de Santa Anna, tan tristemente célebre después en los fastos de los pronunciamientos. Iturbide despachó a sofocar la rebelión, a su amigo y hechura, el general español [José Antonio] Echávarri, que faltando hasta a sus compromisos per-

\footnotetext{
${ }^{8}$ Subrayado del autor.
} 
sonales con el emperador, fraternizó al fin con los republicanos, y unidos los sitiados y los sitiadores, en nombre de la nación, siempre soberana, dieron a la luz el día 2 de febrero de 1823 , el tercero entre los planes de que ha sido tan fecunda la revolución mexicana, conocido con el nombre de Casa Mata, y destinado a poner vergonzoso término a la farsa del imperio, y a inaugurar otra serie de comedias políticas que serían risibles si no hubiesen costado y siguiesen costando tanta sangre a la humanidad.

Puesto el emperador a la cabeza de su ejército, daba muestras de combatir esta vez de veras; pero al fin después de inútiles negociaciones, sin tirar la espada de la vaina por evitar la efusión de sangre, renunció la corona imperial en manos del Congreso reinstalado de su orden, y el 11 de mayo de 1823 se embarcó con su familia en la Antigua, cerca de Veracruz, para Liorna, de donde no debía volver un año después sino para parodiar el desembarco de Cannes y ser bárbaramente fusilado como un proscrito en Padilla, por esos mexicanos, sus paisanos, a quienes según ellos mismos, había con tanta gloria redimido del brutal despotismo de los trescientos años.

Dueño el partido republicano del poder, se apartaron los heterogéneos elementos que bajo su bandera pelearon para derrocar el imperio; y como ni los restos del partido español podían ya compaginarse, ni el borbonista tenía objeto por el momento, formáronse dos partidos beligerantes en el campo de la política, el uno republicano exaltado o federal, lleno entonces de ilusiones y de vida, y el otro republicano moderado, en el que se agruparon los pocos elementos de orden que ya poseía aquella sociedad, así como los hombres de más saber. La primera batalla que se dieron fue en la cuestión del carácter de constituyente o convocante que debía tener el congreso reinstalado. Preferían los moderados el primero, porque tenían más confianza de hacer aceptar sus ideas de orden a este congreso que la que hubiese de elegirse bajo el influjo de la efervescencia del momento, y los exaltados el segundo, por la razón contraria. Triunfaron éstos, y el nuevo congreso constituyente se reunió el 5 de noviembre de 1823; dio el acta constitutiva del gobierno federal en 31 de enero de 1824 , y la constitución 
federal, copiada en su mayor parte del modelo norteamericano, que empezó a regir el $1^{\circ}$ de enero de 1825 . Entronizaba así la revolución, y habiendo llegado casi de un salto a su apogeo, debo ya considerar su acción sobre aquella sociedad.

El Español, 14 de noviembre de 1847.

\section{Artículo V}

Revolución puede decirse de girar perpetuamente en un círculo, o del desorden y trastornos que los medios que ellos emplean acarrean al estado social. Las sociedades antiguas parecían moverse en el círculo de la monarquía, primero electiva y después hereditaria, la aristocracia, la democracia, y vuelta a la monarquía; engendrándose recíprocamente algunos siglos en correr este círculo, que Francia agitada por un movimiento febril ha recorrido en una docena de años. Exageradas ideas de libertad hicieron en 1789 insoportable el despotismo, aunque atenuado por un rey virtuoso y unos ministros sabios, cayó el poder en manos de una aristocracia de riqueza y de saber, que habiendo tenido necesidad de remover hondas pasiones en el pueblo y de apelar a su heroísmo para repeler la inminente invasión extranjera, sin otra culpa tuvo que abdicarlo en una violenta democracia, ejercitándolo ésta con inaudito vigor: a su vez lo inutilizó y dejó a la sociedad huérfana de su amparo, obligada en consecuencia a buscar un asilo contra la anarquía en el despotismo. La monarquía militar reprodujo la antigua de nacimiento, que a su vez engendró a la monarquía representativa de 1789, cuyo roto hilo han reanudado las hábiles manos del [actual] monarca reinante [Luis Felipe de Orleáns].

Bien se echa de ver que la vida íntima de la sociedad moderna no puede encerrarse en este círculo de hierro; ella se agita en sus más hondas entrañas. En esa vida íntima entra como elemento esencial la libertad. Libertad necesitan las artes, las ciencias, el trabajo, la conducta, el hombre, en fin, para moverse y progresar en cualquier sentido; 


\section{LUIS MANUEL DEL RIVERO}

pero no es éste el único elemento, ni dudo que existan otros, debe él avasallarlos tiránicamente, cual lo hace la libertad revolucionaria, sino armonizarse con todos, pudiendo sólo de esta feliz armonía resultar la salud de la vida general y privada. No existe sólo el hombre, que existe la sociedad que le engendra y reclama en pago sus servicios; no sólo la razón privada, sino también la pública, que le sirve de freno y de guía; la voluntad de cada uno tiene que combinarse con la de los demás; en fin, la sociedad de hoy, producto de la de ayer, ha de dar a la luz la de mañana, y cada cosa así se encadena, sin que nada viva fuera del gran todo, animado a su vez por el soplo de Dios.

Al lado, pues, de los derechos individuales, existen los colectivos; al lado del derecho del libre examen, el de la tradición; en una palabra, al lado del derecho de la libertad existe el derecho de la autoridad en ciencia, en religión, en política, en todo linaje de acción. Pero la libertad revolucionaria con nada se aviene y con nadie quiere partir su imperio: ella proclama la ley de la fuerza; dice que el número debe mandar, e introduce así una guerra intestina, un antagonismo de intereses, de sistemas, de clases y condiciones, que realmente han convertido a la sociedad en un campo de Agramante, ${ }^{9}$ después de disueltos

152 los lazos que de antiguo la mantenían unida. ¿Quién hará brotar la luz de este caos? ¡Dichoso mil veces Pío IX siquiera por haber intentado armonizar la religión con la libertad política, principalísima parte del gran problema, y abolir la libertad revolucionaria! ${ }^{10}$ Las universales simpatías que encuentra en su camino, deben de haberle advertido que trae entre manos la causa santa de la humanidad.

La enfermedad revolucionaria que por acá nos aqueja, ha hecho aún mayores estragos en la sociedad mexicana, cuerpo político de complexión mucho más débil que el nuestro. Esta debilidad se funda entre otras causas en la pequeña cifra de la población relativa. Consi-

${ }^{9}$ Campo de Agramante. Lugar donde hay mucha confusión y es difícil entenderse.

${ }^{10}$ Rivero se hace portavoz de la opinión que hasta 1848 prevalecía sobre Pío IX, el cual era considerado un Papa liberal. 
dérese una población de siete millones de almas a que pueden haber llegado las antiguas provincias del virreinato refundidas en los 24 departamentos de la República, diseminada por el inmenso territorio comprendido entre $\operatorname{los} 80^{\circ}$ y $126^{\circ}$ longitud occidental de París, y entre $\operatorname{los} 16^{\circ}$ y $42^{\circ}$ lat. ber., [sic] cortado de Norte a Sur por la gran cordillera de la Sierra Madre que ostenta sobre sus costados todos los climas y producciones, bañado de ríos y de lagos considerables, sin medios artificiales de comunicación, y se vendrá en conocimiento de la más poderosa causa de debilidad en la nacionalidad mexicana.

El genio de los españoles, luchando victoriosamente con estos grandes obstáculos, realizaba las comunicaciones con los puntos más distantes con una celeridad sorprendente, y hacía participar de los beneficios del comercio y del gobierno al más oscuro rancho: empleaba para ello una inmensa arriería, y el abundante ganado caballar que allí se criaba lozano y se prestaba a marchas las más veloces y fatigantes. También el gobierno español, que ya había entrado en esta clase de mejoras, dejó aunque sin concluir una hermosa calzada que desde Veracruz sube a México, en la que se ve el magnífico Puente del Rey, hoy Puente Nacional, única mejora que debe el país a la revolución, este cambio de nombre, pues por lo demás no se ha hecho una sola vara de carretera regular ni en esta vía ni en ninguna otra. No pudiendo llamarse con este nombre las que se han abierto entre Guadalajara y Tepic, y algunos otros puntos reducidos a una mala explanación del terreno. Así es que si las diligencias circulan por la República, es a fuerza de trabajo e industria, y por caminos naturales, habiendo un español, el señor Zurutuza, ${ }^{11}$ logrando en estos últimos años organizar este importante servicio a fuerza de genio y perseverancia.

Otra de las causas principales de la debilidad de aquella nacionalidad está en los heterogéneos elementos de población. Más de una mitad de ella, y aun las dos terceras partes, la forma la raza indígena pura, que participando de las variedades de los climas y localidades

${ }^{11}$ Anselmo Zurutuza, empreario vasco, socio de Manuel Escandón en el negocio de las Diligencias de México. 


\section{LUIS MANUEL DEL RIVERO}

que habita, vive aparte de la raza europea y forma una especie de Gesen en aquel Egipto. Vienen luego los rancheros y los léperos que forman el pueblo bajo de las haciendas y de las ciudades, gente ya más en contacto con los blancos, de cuyos vicios y pasiones participan, por quienes se prestan a servir en toda clase de faenas y a batirse en el ejército, instrumento ciego en fin de que se puede hacer buen o mal uso. Encima de ellos están los artesanos, pequeños propietarios, traficantes y mercaderes al pormenor, gente que se ha aumentado después de la independencia, y que forma la única clase media de aquella sociedad, muy preocupada contra España, y mucho más contra los extranjeros que vienen a competir con ellos, poco instruida y muy apegada al nuevo régimen y a la federación si bien hoy va rectificando sus ideas. Vienen por fin las clases altas del comercio, de la administración, del ejército, de los grandes propietarios, del foro y de la Iglesia, en cuyas manos ha rodado el poder desde la independencia, y que son responsables de cuanto ha sucedido. Estas clases no carecen sin duda de patriotismo; pero ni su instrucción y aptitud para los negocios están al nivel de su tarea de gobierno, ni su moralidad, salvas honrosas excepciones, ha podido resistir el influjo letal de un continuo estado de desorden, contaminándose en consecuencia por un egoísmo siempre creciente.

Con todos estos defectos y nulidades, el gobierno español había logrado hacer de México un gran cuerpo de nación, que funcionaba admirablemente y daba de sí resultados de paz y constante progreso; todo esto sin bayonetas, por sólo el ascendiente del poder civil combinado con la acción benéfica de la Iglesia, y teniendo que resolver los más arduos problemas de administración. Me parece que ninguna colonia ni a una nación puede gloriarse de un período igual de bienestar, de justicia y de íntima tranquilidad; resultado inmenso que honra sobre todo elogio a la paternal e inteligente administración española. El virrey y la audiencia coronaban la administración, pero había otra audiencia en Guadalajara para la más pronta expedición de los negocios judiciales que casi todos fenecían en el país, siendo tan raros los recursos al soberano, que en veintidós años que llevaba de ministro en 
LA GUERRA DE MÉXICO

1808, decía uno de los fiscales de la audiencia de México, no haber visto más que una segunda suplicación llevada a efecto. El virrey estaba dotado por las leyes de Indias de facultades amplísimas, y en los casos arduos podía con consejo de la Audiencia proveer a toda eventualidad.

El territorio, aunque inmenso, estaba compartido de modo que la acción pública llegase fácilmente a todas las extremidades. La península de Yucatán, si bien parte del virreinato, estaba regida por un gobierno que se entendía directamente con la corte de Madrid, a fin de que las medidas que exigía su situación excepcional, no encontrasen con el estorbo de multiplicados trámites y dilaciones. En el mismo caso se hallaba la comandancia de las Provincias Internas, que por su posición avanzada hacia el Norte y el Oeste, por su contacto con tribus salvajes sumamente belicosas, exigían una protección especial. Ésta la encontraron eficacísima en las medidas dictadas por la corte y ejecutadas por dicho comandante a propuesta del visitador Gálvez, enviado al efecto sobre el terreno por la ilustrada solicitud de Carlos III. Cifrábanse a más del fomento de las misiones inspiradas por el celo apostólico español, en un hábil sistema de colonización militar por toda la inmensa línea de fronteras del Noroeste, bajo la protección de presidios o fortalezas, y en otro igualmente hábil sistema diplomático, pues el comandante hacía con las diferentes tribus tratados, en que no se avergonzaba de comprar la paz con raciones, efectos de comercio y otras concesiones. Así prosperaron admirablemente Durango, Chihuahua, Nuevo México, Sonora y la Alta California; países asolados desde la independencia por las frecuentes incursiones de los salvajes, que todo lo llevan a sangre y fuego.

Así pues, todas estas posiciones tan distantes, todos estos miembros tan heterogéneos estaban unidos en un cuerpo firme de nación por el lazo de la justicia que se distribuia a todas bajo las inspiraciones de una ley común, que sólo doblegaba en entereza y vigor delante del menor, de la viuda y señaladamente del indio, sometido a una ley especial mucho más indulgente y benéfica; lo estaban por la acción no contradicha, antes universalmente acatada, de una administración ilustrada, que 


\section{LUIS MANUEL DEL RIVERO}

hacía sentirse en las extremidades tan fácilmente como en el centro; lo estaban en fin por una religión que venía a llenar las lagunas de la ley, a inspirar la caridad mutua en todas las clases, el respeto de todas a la autoridad: tal era el alma que vivificaba este cuerpo.

La revolución disolvió este lazo, mató esta alma, y quedó el estado compuesto de pequeños estados o departamentos indiferentes y aun hostiles entre sí, que adoptaron por base de su conducta el propio engrandecimiento y la disminución de los servicios y cargas impuestas para el bien general. Por su parte, el gobierno central en todo tiempo, les correspondió en igual moneda, y sólo se ha ocupado de los departamentos desde la independencia, para enviarles mandarines que les oprimían con su tiránica conducta, y exigían de ellos lo poco o mucho con que contribuían a la común defensa, lo que es fin tan corta cosa, que hace muchos años que aquel gobierno sólo se sostiene de los sacrificios de la capital y sus inmediaciones, y eso en momentos tan apurados como los de una pérfida invasión extranjera. Los departamentos del centro, San Luis Potosí, Guanajuato, Michoacán, Aguascalientes, Jalisco y Zacatecas, en lo que piensan y están tratando hace tiempo, no es tanto en defenderse de los yanquis, como en sustraerse

156 a la dominación de México, formando una republiquita independiente de dos y medio millones de almas. Los más lejanos de Durango, Chihuahua, Nuevo México a sus propios recursos, en lo que les hace un gran favor, sólo miran alrededor casi para proveer a su defensa contra las devastaciones horribles de los indios salvajes, y no será extraño verlos definitivamente unirse a los americanos, si son capaces de prestarles este amparo, de que han carecido desde la independencia contra un enemigo $\tan$ feroz.

La revolución además quitó todo prestigio a la autoridad, enervándola en consecuencia e inutilizándola para el bien. Así como no es posible idear un estado en que la autoridad sea objeto de un culto más rendido aún en las personas de sus últimos ministros como sucedía en tiempo del gobierno español, así tampoco puede darse otro en que sus ministros aun los más elevados son menos considerados cuando no vilipendiados, que en el día lo son. Empezando por los magistrados, 
ellos no se han multiplicado por toda la República, creándose una audiencia en cada departamento, sino para pasear por toda ella la vergüenza del gobierno en la desnudez y aun completa destitución en que los tiene, a la vergüenza propia en los pocos que se atreven a ostentar un bienestar comprado a precio de su conciencia. Los empleados civiles viven en la misma penuria, acostumbrados casi desde la independencia a cobrar en papel que los toman los agiotistas a un 8 o un $10 \%$ de pago, para colocarlo ellos por todo su valor con el gobierno. Los militares son los únicos que cobran, porque se pagan a sí mismos, aunque con la desigualdad y las extorsiones consiguientes. Nada digo de los ministros secretarios del despacho, de los generales y demás altos empleados, que han llegado a hacerse cosa tan vulgar y prosaica a fuerza de repetida, que nadie repara en ellos.

Con esto la autoridad, de origen casi divino según las tradiciones españolas, se ha humanizado tanto y hecho tan trivial, merced a la revolución que primero destruyó aquellas tradiciones y luego ha mantenido a los ojos del público siempre vivo el aflictivo espectáculo de los pronunciamientos, que realmente la sociedad aquélla se encuentra hace muchos años huérfana de su égida y en un estado semianárquico, mantenida en cuerpo por la intriga y por la fuerza.

En los primeros momentos el entusiasmo de la libertad y de la independencia pudo encubrir y aun en parte corregir estos vicios. La administración española había dejado en buen estado la Hacienda, y el país, aunque trabajado por la guerra civil, no estaba agotado como lo ha estado después. Ingresaba además el capital europeo, y sobre todo el inglés por las vías del empréstito y de las locas especulaciones de minas, suscitadas por la emancipación. Los primeros años se pasaron, pues, gloriosamente y no sólo los particulares sino el gobierno, contrajeron el hábito de despilfarrar, creyendo inagotable la mina de la riqueza. Mas considérese en movimiento toda la inmensa máquina del federalismo, sus veintiuna legislaturas compuestas de un congresito y de un senado, con más el Congreso General, unido esto a la multitud de empleados exigidos por la administración; considérese la milicia nacional dominando las localidades, el ejército con las ínfulas de libertador 


\section{LUIS MANUEL DEL RIVERO}

de la patria, la imprenta libre ejercida por un pueblo nuevo, los clubs además atizando el fuego, y dígase después si había aquí campo para que se cebasen las ambiciones privadas y las pasiones de todo género.

Por lo años de 1826 y 1827 , resucitó este desorden, y la crisis de la fiebre revolucionaria, el ministro norteamericano Poinsett, que abusando lo enormemente de su posición, y faltando a todas las reglas del Derecho Internacional, se mezcló de una manera odiosa en los negocios del país, nada menos que organizando el famoso club de Nueva York, [logia yorkina] foco de todos los revolucionarios más violentos, y aun centro del mismo gobierno. Fraguóse la conspiración del Padre Arenas, que fue decapitado con el general Arana y otros españoles. Salieron también desterrados los generales españoles [Pedro Celestino] Negrete y Echávarri, brazos principales del Plan de Iguala. Sea lo que quiera de esa supuesta conspiración, es lo cierto que nada tenía de seria y que en nada pensaban menos que en conspirar los laboriosos y pacíficos españoles residentes en la república; pero el club de York pidió su proscripción en masa, y fue necesario expelerlos de toda ella, destrozando para ello la sociedad mexicana. Siguióse contra los ministros el saqueo del Parián, emporio del comercio español en la capital, viniendo este tiro de la misma mano. El triunfo conseguido por las intrigas más que por las armas del general Santa Anna contra la loca expedición de Barradas, vino a poner el colmo a la exaltación; y a coronar la obra de Poinsett. No sabemos en qué hubiera dado ya la revolución; asegúrase que después de haber destruido a los españoles y su obra, quería ahora emprenderla con todo blanco y sus descendientes, sirviéndose para ello del ministerio de la raza indígena, y que tal fue el designio del Plan de Texcoco.

Mas sea de esto lo que quiera, tuvo lugar en 1830 una reacción del orden, y el Plan de Jalapa vino a aliquebrar la revolución, resultando triunfante contra Santa Anna el general Bustamente, que había peleado en nuestras filas hasta el Plan de Iguala; militar valiente y hombre de bien, pero sin aptitud para el primer mando, sobre todo en circunstancias tan críticas. Sirvióse de don Lucas Alamán, que fue su alma de su gobierno por espacio de dos años, y que hizo los mayores esfuer- 
zos por organizar el país, y detener el torrente revolucionario. Era un antiguo alumno de las escuelas de París y en la segunda época constitucional había representado a su patria en las cortes españolas. Pero el dique hubo de romperse y después de varias vicisitudes, se inauguró de nuevo en el poder el partido moderado en 1835, teniendo esa vez a su frente al general Santa Anna, duende de los pronunciamientos, y por su mentor el licenciado Tagle, ${ }^{12}$ hombre de estudio, que dio a luz una difusa Constitución central en oposición a la federal de $1824 .^{13}$ Rigió ésta con su acostumbrado cortejo de pronunciamientos hasta el Plan o las Bases de Tucubaya en fin de 1841, época en que Santa Anna rehabilitado de su antigua desgracia de San Jacinto (en 1836 fue hecho prisionero por los texanos), volvió a ser el supremo regulador de los destinos de la República, según se intituló en una ocasión.

Pero Santa Anna, viva personificación de la intriga mexicana, que por esta cualidad y alguna firmeza, es casi el único hombre capaz de mandar a sus paisanos en estos momentos de desorganización, se ha mostrado siempre tan hábil para escalar el poder, como incapaz de mantenerse en él, porque para esto se necesitan los talentos y la honradez del hombre de estado, de que él carece completamente. A su vez, pues, en fin de 1845 hubo de ceder el puesto al general Paredes, ${ }^{14}$ antiguo oficial en nuestras filas, militar pundonoroso y valiente, hombre honrado, a quien se ha atribuido el designio sumamente grato al clero y altas clases de México, de preparar el advenimiento de la monarquía borbónica. ${ }^{15}$

${ }^{12}$ Francisco Manuel Sánchez de Tagle (1782-1847). Abogado, poeta y político.

${ }^{13}$ El propio Luis Manuel Rivero realizó un exhaustivo análisis de la Primera República Centralista en su libro: México en 1842, 1844, Madrid, Imp. y fundición de D.E. Aguado. Sobre la Constitución centralista de 1836, Vid, Reynaldo Sordo Cedeño, El Congreso en la Primera República Centralista, 1993, México, El Colegio de México-ITAM.

${ }^{14} \mathrm{E} 1$ autor sufre aquí una confusión, pues Santa Anna fue arrojado del poder en diciembre de 1844 y sustituido por José Joaquín Herrera, quien a su vez fue suplantado por el general Mariano Paredes en diciembre de 1845.

${ }^{15}$ Nótese que Rivero guarda una cierta distancia de este designio tan grato a los círculos moderados españoles. 


\section{LUIS MANUEL DEL RIVERO}

Pero sólo el anuncio de este designio bastó para dar vida al partido federalista y para traer del destierro a Santa Anna, que hermanado con Gómez Farías, jefe de aquél, se entronizó de nuevo. Los federales, fieles a sus doctrinas, echaron mano de los bienes de la Iglesia, y la pusieron en el caso de vender por 16 millones de duros [producto de la venta forzosa] de sus fincas. La Iglesia que ha estado vendiendo continuamente para subvenir a los incesantes apuros del erario, y que señaladamente había asistido a Paredes, se resistió a semejante despojo. Ésta y otras hazañas del partido federalista, produjeron un pronunciamiento en México [la rebelión de los polkos], hecho por la gente que tiene que perder, contra los que nada o muy poco aventuran en los trastornos públicos. Acudió Santa Anna [al frente] del ejército y poniéndose al lado de los últimos, derribó a su compañero [Gómez] Farías; [tal es el] estado presente de la precaria situación de los partidos en aquel desgraciado país.

La autoridad, pues, desprestigiada completamente por el influjo de la revolución, no sólo ha dejado disueltos los lazos que mantenían unido el territorio, sino los que ligaban a las diferentes clases; ha dejado mexicanos contra extranjeros, léperos contra hombres de levita, militares contra paisanos, revolucionarios contra hombres de orden, Iglesia contra el Estado, y por último el sistema peor de todos raza indigena contra raza blanca. ${ }^{16}$ Todo esto se hallaba antes hermanado, se hallaba unido: en su lugar ha sucedido un horroroso antagonismo, que aún no ha dado todos sus frutos, pero que puede darlos muy en breve con el brazo de los salvajes del Noroeste, de los indios pintos del Sur que de algunos años acá todo lo llevan a sangre y fuego, habiendo literalmente arrasado la ciudad de Chilapa y de los indios de Tabasco que han empezado a dar iguales muestras. Ésta es la obra de la revolución.

El Español, 18 de noviembre de 1847.

${ }^{16}$ Subrayado del autor. 
LA GUERRA DE MÉXICO

\section{Artículo VI}

No se crea que la revolución mexicana no ha hecho nada bueno; pero este bien es tan corto, que no basta para disculparla por el mucho mal que ha causado, y sobre todo, por esa profunda desorganización, que descendiendo desde la cima hasta el pie de la escala social, ha enervado completamente el país, arrojándolo sin honor a los pies de un orgulloso vencedor. Esto es ciertamente muy grave: algunos, como para ofrecer a la víctima un consuelo por tan inmenso infortunio, dicen: "Sí, pero el país ganará." No negamos nosotros que ganancia tiene que haberla, cualquiera que sea la mudanza que ponga término a un tan abyecto estado de cosas, y que al menos bajo los americanos habrá orden y progreso material; pero no hay bienes ningunos capaces de resarcir el honor perdido, de colmar el vacío dejado por la pérdida de la independencia; creemos que el honor y la independencia es lo último que respeta la desgracia, lo último que tiene que perder un pueblo lo mismo que un individuo, y que cuando se ha llegado a este abismo de desventura, es necesario despedirse de la vida.

Dicen otros, ¿qué importa a la humanidad el que subsista o desaparezca la nacionalidad mexicana? Lo que realmente le importa es, que el privilegiado suelo que ella ocupa sea restituido a la cultura de la civilización. Pero yo que me precio de humanitario, no tanto sin embargo, que no deje en mi corazón un puesto privilegiado para el más decidido patriotismo; y este sentimiento, tan puro cuando menos como el primero, se lastima horriblemente de que se disipe como el humo el patrimonio de honor y de riqueza acumulado en las manos necias de un heredero presuntuoso por la sobriedad, por la virtud, por el trabajo infatigable y oscuro de muchas generaciones de honrados y animosos españoles. La humanidad, por otra parte, no gana con la supresión de grandes y legítimas nacionalidades: ella prefiere antes bien verse completamente representada en la tierra, y para esto ha derramado con variedad sus tesoros, invistiendo con una parte de ellos a cada raza, a cada pueblo. Enhorabuena que estas grandes unidades se salgan al 


\section{LUIS MANUEL DEL RIVERO}

encuentro en el camino de la vida para auxiliarse mutuamente con afecto fraternal, mas nunca para combatirse y para absorberse. Creo, pues, que al interesarme por la noble nacionalidad española en el Nuevo Mundo, me intereso realmente por la causa de la humanidad, y muy especialmente por la de la América, en cuyo suelo está ya sobradamente representada la raza sajona con todos sus instintos, con todas su perfecciones y defectos.

Pero ello es lo cierto, que tenemos que asistir como curiosos al espectáculo de vandalismo coloreado con una falsa tinta de civilización, que en la mitad del siglo XIX está ofreciendo a la vieja Europa la original e ilustrada América; ello es, que la revolución que ha amortecido el brazo que debiera alzarse vigoroso en México para defensa de nuestra nacionalidad, ha herido también el nuestro de parálisis, e impidiéndonos llevar a nuestros hermanos el socorro debido a la hora del infortunio; ello es que Scott ha llevado tan lejos la burla, que ha osado, sin infringir ninguna regla de prudencia militar, comprometerse en el corazón de un país enemigo a cien leguas de su base de operaciones, a través de formidables posesiones, y a la vista de un ejército que le oponía siempre un cuádruplo de fuerzas, y al que en

162 fin, ha destrozado delante de una ciudad de más de 200,000 habitantes, que no ha podido comunicarle alientos, ni aun a sí propia salvarse. Esto no es guerra, ni valía la pena de escribir sobre ello; el público español lo sabía ya con tanto dolor como sorpresa: lo que más puede interesarle, después de llorar sobre los muertos, es interiorizarse un poco en las causas y fines de esta invasión inicua, en las tendencias de la política americana; para lo cual, con la venia de nuestros lectores, de cuya paciencia acaso estamos abusando, como de la generosidad del ilustrado periódico que nos ha abierto sus columnas tomaremos las cosas de un poco atrás, sin perjuicio de ser muy breves.

Al transportarnos de México a Washington, nos sentimos en una nueva región rodeados de diversa atmósfera, sometidos a distintos influjos. No es ya sólo nuevo el país, que realmente contrasta con el que dejamos, país mucho menos rico, menos amigo del hombre, y que también sus habitantes, y el principio de sociabilidad que los reúne, 
tan feraz como es el suelo de México, benigno en general su clima, muelles e indolentes también en lo general sus habitantes, es comparativamente pobre el suelo de los Estados Unidos, duro su clima, activos y previsores sus hijos. No intento injuriar ni ensalzar, sino simplemente dar cuenta de la impresión que produce en el viajero el aspecto de ambas sociedades. Mientras que nadie se apresura por nada en la primera y si de algo hay prisa es de gozar, la segunda es una colmena donde todos entran y salen, donde apenas hay un instante de respiro, donde se sueña en ganar. Esta necesidad de movimiento, este deseo de adquirir, forman según la naturaleza en el norteamericano, dando lugar en él a muchas virtudes y vicios, porque dicho se está que si el trabajo engendra las primeras la codicia produce los segundos, y señaladamente un egoísmo desenfrenado, que es el vicio capital de aquella sociedad, fundada casi exclusivamente sobre el individualismo. En México por el contrario, los vicios nacen de otro extremo, y la molicie produce la disipación y un furor de juego tal, que contaminando desde lo más alto a lo más bajo, es una de las causas principales de la enervación del cuerpo social. Vicios tenía la antigua sociedad hispanoamericana la cual, sin embargo, no flaquea de desapego al trabajo, siendo la existencia de un español en América el tipo de la laboriosidad, de la honradez y de la abnegación; pero en la nueva sociedad, abandonada a sí misma y en contacto con la levadura de desorden, han brotado con fuerza vicios que sólo existían antes en germen o balanceados por otras virtudes.

La sociedad norteamericana se funda esencialmente sobre el principio democrático, sobre el concurso de todos, a los negocios de todos. La Corona no hizo otra cosa que expedir cartas de concesión a los diferentes colonos, o bien a grandes del reino, o a compañías, las cuales al cabo de tiempo y de ímprobo trabajo lograron crear establecimientos diversos sobre la orilla del Atlántico; sin ninguna ligazón entre sí, sin más contacto con la metrópoli que el de los gobernadores que se les remitían, y que salvo algunas restricciones, les dejaba en plena libertad para gobernarse interiormente, para imponerse contribuciones y para todo género de negocios de común interés. Así se 


\section{LUIS MANUEL DEL RIVERO}

formaron con los puritanos y otros emigrados arrojados por las discordias intestinas de Inglaterra, sobre todo en los reinados de Jacobo I, de Carlos I, Cromwell y Carlos II, las colonias de Virginia, de Nueva Hampshire, de Massachusetts, de Connecticut, de Providence, de la Carolina, de Nueva York, de Pensilvania y otras, por los esfuerzos casi exclusivos de los particulares. Cuando al salir de su penosa infancia después de la paz en 1763, quiso el parlamento reivindicar el derecho de imponerles contribuciones sin consultar a sus legislaturas, siendo éste un atentado contra el derecho de que se hallaban desde sus principios en posesión pacífica, después de inútiles reclamaciones se levantaron en masa para defenderlo, y en fin, para declarar a la faz de Dios y de los hombres en 1776 que se habían disuelto los lazos que los ligaban a la metrópoli y entraban en la comunidad de las naciones independientes. Así la independencia, lejos de dañar ni de turbar en lo más mínimo su estado social, vino antes bien a corroborarlo y sancionarlo de una manera definitiva. Muy al contrario sucedió en las colonias españolas. Habiéndose hecho la conquista y el establecimiento a nombre y a costa de la Corona, habiéndolos organizado ésta, gobernado y defendido constantemente, sus sagrados derechos fueron imprudente-

164 mente conculcados por una insensata revolución, que contrariando el principio de autoridad que animaba su estado social, se convirtió en causa permanente de debilidad y de ruina para las mismas.

El pueblo de los Estados Unidos se considera además como una misión providencial, la de poblar y civilizar el nuevo continente; objeto grandioso que mueve todos los resortes de saber, y lo llena de una indecible animación y poesía. Así, pues, es un ejército siempre en marcha, cuyas fuerzas gastadas por la incesante fatiga y la necesidad de ocupar el país que deja a la espalda, se rehacen cada día sobre el mismo terreno, y señaladamente por los numerosos reclutas enviados por Europa a la voz de sus hazañas prodigiosas, y que le comunican su espíritu aventurero. Los escritores, los hombres de Estado, el gobierno mismo, todos contribuyen a fomentar en el pueblo esta pasión inmensa que hasta hoy se ha nutrido de las pobres tribus, víctimas sacrificadas en el altar de esa desmesurada ambición de una manera 
LA GUERRA DE MÉXICO

tan bárbara como hipócrita, y que exige ya un alimento más nutritivo en las ricas posesiones ocupadas por un pueblo civilizado.

La voz de marcha de ese grande ejército, que antes tenía la cara hacia el poniente, sin abandonar este interesante punto sobre el Pacífico hoy ocupado por una de sus alas, se ha cambiado ya, y hoy se encamina hacia el Sur, hacia la tierra prometida de México. ¡A México! Es el grito que ha guiado los soldados de $S$ cott, avanzada del gran pueblo que forzando su marcha se apresura a tomar posesión de las fértiles llanuras y ricas minas de este suelo privilegiado; del modo que otro grito análogo conduce a otro pueblo del norte a enseñorearse de otro puesto admirable, cuya posesión valía en sentir de Napoleón el centro del universo. ¡Qué será del mundo cuando los rusos hayan llegado a Constantinopla y los norteamericanos al istmo de Panamá! El coloso del mar [Gran Bretaña] completará entonces el gran triunvirato, si los pobres de Irlanda y de Manchester no le impiden acudir a la cita.

Mas para en fin aspirar sin nota de temeridad a esta inmensa fortuna, ¡qué de trabajo y penosa expectativa, qué de iniquidades e inauditas tropelías! Admiremos sin embargo, los juicios de la Providencia, que no sólo hace concurrir a sus grandes fines las pasiones humanas y los esfuerzos de las naciones, sino que se sirve de unas para castigo de las otras, que ha llamado del Norte al vengador de la justicia oprimida en México, y especialmente conculcada en el grito de independencia, que no fue sino un grito de pérfida rebelión. Día vendrá también en que aparezca otro fuerte brazo vengador de la justicia imprudentemente sacrificada hoy por la ambición desmesurada de los Estados Unidos.

El Español, 21 de noviembre de 1847.

\section{Artículo VII}

Como Roma, luchando quinientos años por asimilarse, la Italia como España rescatando a palmos durante ocho siglos su suelo de manos de un invasor soberbio, como Inglaterra y otros pueblos que han llenado 


\section{LUIS MANUEL DEL RIVERO}

el mundo de una acción gloriosa, los Estados Unidos tuvieron también su infancia laboriosa y dura, en la que adquirieron el acertado temple que exigía su ulterior destino. Estrechados entre los bosques y el Atlántico, colocados sobre una costa inhospitalaria, disputando su humilde morada a las fieras y a los indios, y su existencia a crueles privaciones y todo género de azares, crecieron lentamente con el auxilio de un perseverante trabajo, de grande economía y prudencia. La madre patria, lejos de ayudarlos los trató desde un principio con poca generosidad, sometiéndolos a un régimen egoísta en sus mutuas relaciones. Las colonias no pudieron en consecuencia proveerse de más géneros que los que les proporcionaba el mercado inglés: todo comercio extranjero les estaba prohibido, y aun el nacional se hallaba restringido, inclinando siempre del lado opuesto la balanza: por último, sus productos sólo podían venderlos a los ingleses, y les era prohibida toda manufactura que tuviera sus análogas en Inglaterra. En este pesado régimen fiscal, templado algo por la facultad exclusiva de imponerse tributos, llegaron al período brillante de su independencia, que los encontró rudos y pobres, pero sencillos, valientes y virtuosos.

Acariciados entonces por la fortuna y aplaudidos por el universo,

166 encontráronse unidos en simpatías e intereses después de la paz, como lo habían estado para la común defensa durante la guerra, y el genio de la libertad e independencia vino a infundirles nueva vida, y abrirles la perspectiva brillante de sus nuevos y magníficos destinos. La Constitución Federal de 1789 resolvió de una manera satisfactoria el problema de su organización, pues que por espacio de más de medio siglo ha bastado, no sólo al gobierno del pueblo, sino al más extraordinario crecimiento y prosperidad a que haya llegado jamás en tal período ninguna otra nación de la tierra. Cualesquiera que fuesen sus vicios, ella se adaptaba, pues, a los antecedentes y costumbres de ese pueblo; satisfacía sus necesidades, favorecía su genio y su peculiar destino. Como cada una de esas colonias era un cuerpo político animado por una constitución obró sabiamente al reconocer y sancionar este hecho, respetando en cada estado la más lata soberanía. El lazo federal hubo de ser en consecuencia muy flojo, pero así tenía que ser para que 
subsistiese, y por otra parte se formó tan hábilmente, que los Estados Unidos han podido funcionar admirablemente hasta el día en la comunidad de las naciones independientes, $y$ en cuanto al interior seguir una línea de política, si no siempre justa, al menos vigorosa y popular.

Mil anomalías nos presenta a nosotros, hombres del múndo antiguo, esa sociedad, tanto en sus costumbres como en sus instituciones; pero acaso olvidamos que ella tiene que bregar con la más ruda tarea que jamás se haya impuesto a un pueblo, y que mientras ésta dure, no puede con razón exigírsele pulimento ni perfección en nada. Con todo, $\mathrm{y}$ aun haciendo las concesiones posibles, nos es muy difícil pasar por ese monstruo de la esclavitud, tanto más horrendo cuanto que su fealdad contrasta con la radiante faz del genio de la libertad que en lo demás alegra y vivifica aquellos países, y cuanto que para sostenerlo ha sido necesario sacrificar de la manera más atroz la humanidad y la justicia. En su consecuencia hay una línea que divide ya profundamente la república en estados libres donde el negro goza de la libertad al menos legal, y [estados] esclavos donde esté sometido a la más brutal esclavitud: los del Sur son principalmente los estados negreros, los que trafican en hombres y algodón que por su medio producen; y como su introducción de África está prohibida, hay estados destinados a la cría del negro que sobresalen en esta industria, cual sucede al antiguo de Virginia, así como Kentucky sobresale en el tabaco y Ohio en los ricos perniles. Este repugnante cuadro choca y alarma la conciencia puritana de los estados del Norte, principalmente los de Nueva Inglaterra; pero están reducidos por la Constitución que somete este negocio a la soberanía de los estados, a emitir simples, aunque ardientes votos, o a enviar a aquella maldecida tierra algunos fervorosos abolicionistas que predicando la libertad en su mismo suelo clásico, corren un inminente riesgo de ser colgados en el árbol más cercano de su púlpito por el pueblo soberano, que reasumiendo sus derechos y facultades en virtud de la Lynch-law o ley de Lynch, en el espacio de una hora legisla, juzga y ejecuta por sus manos la sentencia que ha de purgar en la tierra del monstruo que aspira a establecer en ella la igualdad y la fraternidad de las razas. 
Durante la primera presidencia del demócrata Jackson, corrió la Unión un grave peligro de disolución por los "nulificadores" de la Carolina del Sur dirigidos por Mr. Calhoun, uno de los jefes entonces del Partido Democrático o loco-foco que negaban al Congreso Federal la facultad de disponer por medio del arancel; de la suerte de la riqueza pública sacrificando como lo estaba haciendo en la guerra de las tarifas los estados del Sur esencialmente agricultores, al bienestar de algunos manufactureros de la Nueva Inglaterra. Pretendían además que el [Congreso] no podía en lo más mínimo alterar la esclavitud ni introducir en ella directa o indirectamente la menor mejora, ${ }^{17}$ siendo esto peculiar de los estados. La crisis se decidió por un Bill de compromiso redactado por Mr. Clay, uno de los jefes del Partido Whig o conservador, en que se contestó a la codicia aliviando los derechos de los artículos extranjeros que no ofrecían competencia a la industria nacional, y dejándolos subsistir en los demás: pero se sacrificó la humanidad abandonando los negros a la merced de los "nulificadores". Este punto es doblemente interesante para calificar el estado de las ideas y la moralidad de los partidos en aquel país, y para conocer una de las principales causas de la invasión de Texas, debida a la preponderancia que van adquiriendo los estados negreros del Sur, y que con los intereses ya bastante divergentes de los del Oeste, tiende a romper la Unión y a despedazarla muy pronto más tarde en tres grandes grupos inconciliables: el del Norte y el Este, el del Oeste y el del Sur.

A pesar de ésta y otras anomalías, que aun sin tener la delicada conciencia de los descendientes de los peregrinos, no podemos comprender ni digerir los envejecidos hijos de este viejo mundo, el pueblo de los Estados Unidos ha crecido portentosamente en riqueza y en población, calculándose que ésta se duplica en veintitrés años, y que aquélla se aumenta en escala aún mayor; todo bajo los auspicios de esa magnífica Constitución que también se ha plegado a la estructura física y moral de la sociedad, para cuyo régimen se concibió. Este pueblo que comenzó hace poco más de dos siglos; que en 1688 en el

${ }^{17}$ Subrayados del autor. 
momento de la revolución inglesa tendría 20,000 almas, y al salir de su revolución un siglo después unos tres millones y medio, encerrados en una lengua de tierra sobre el Atlántico, hoy cuenta en su seno muy cerca de 20 millones de hijos (incluso dos y medio a tres de negros esclavos) que traspuestos los montes Apalaches se han derramado con la plenitud del río que le fertiliza en el gran valle del Misisipí, antes surcado por tribus vagabundas, hoy poblado de ricas ciudades donde se desenvuelve en colosal escala el drama de la vida humana bajo el influjo de la más adelantada civilización. Este gran resultado se debe también a la inmigración.

La América del Norte sigue siendo el asilo de la humanidad, el imán poderoso de la población europea, que azotada de tantas guerras, desastres y revoluciones, va a buscar en aquel suelo abundante y pacífico el reposo del trabajo protegido y no esquilmado por el gobierno, la tranquilidad de una conciencia libre de toda opresión y tiranía. Esta inmensa libertad es la que hace llevaderos y aun dulces los afanes, y a veces la miseria con que de pronto se encuentra allí el emigrado europeo, ya sea luchando en el corazón de los bosques con su rifle y su hacha, ya en situación algo mejorada rompiendo el duro seno de aquella tierra virgen, ya abriendo los inmensos canales y caminos de hierro que cruzan en todos sentidos aquel vastísimo país.

En los cuarenta primeros años de este siglo, calcúlanse por un cómputo bien bajo, en un millón de hombres los emigrados europeos que ha recibido la Unión; hombres, que por más que suenen, miserables, son jóvenes y robustos, muchos de ellos artesanos, y que por consiguiente han llevado a las venas de aquella población su sangre más sana y espirituosa. Desde el año [de] 1840 ha aumentado grandemente la emigración, y se calcula en 200,000 almas las que anualmente han formado desde entonces la misteriosa corriente humana, que desde el principio del mundo sigue de oriente a poniente, y que esta vez parece fijada en Norteamérica incluso el Canadá; habiendo en el año de 1846 salido de Inglaterra 82,000 y pico de hombres con el primer destino, y 42,000 y pico con el segundo, y subiendo a 60,000 los que partieron 
de Alemania. Este año se calcula que el número de emigrados europeos no bajará de 300,000 .

México ha estado privado hasta el día de este auxiliar poderoso. Por más que se haya abierto a la emigración, que la haya solicitado con ahínco y aun gastado inmensas sumas en fijarla en su suelo; ella ha esquivado sus favores y ha preferido las escaseces y penalidades que la aguardaban en la otra región, semejante en esto a la venturosa aldeana, que antepone a la torpe seducción de rico voluptuoso el basto abrazo de pobre pero honrado marido. Consistía en que México no se abría sino a medias, y al través de doradas promesas dejaba entrever el amargo fondo de la más innoble servidumbre civil y política, la estúpida dominación de cuatro mandarines sin fe y sin costumbres. Hasta la época de la independencia tuvo aquella sociedad por toda emigración la noble sangre castellana que la vivificaba en todos sentidos. Desde entonces ha sido tal la ceguedad de aquellos hombres de Estado, que no pudiendo atraer ni cosecharse la emigración europea, en un acceso revolucionario volvieron una mano impía sobre ese mismo raudal de vida que les quedaba en la sangre española, y lograron completamente cegarlo. Pero esta hazaña tienen que compartirla con el ministro norteamericano de que llevamos hablando.

Así pues, una de las primeras necesidades de la Unión Americana desde la independencia ha sido el terreno, y terreno han tenido y logrado por toda clase de medios, no todos justificables, mucho menos a los ojos de quienes se precisan de descender de los célebres peregrinos y del famoso Guillermo Penn, de los hombres en fin que escapados al naufragio del mundo viejo, a las abominaciones de esta prostituta, ${ }^{18}$ salvaron en la tabla de la Biblia la fe de la humanidad, el imperio de las ideas morales. Los títulos con que han ido adquiriendo el terreno, los han derivado en gran parte de los indios, cuyas tribus les cedían, por medio de tratados y en cambio de algunos rifles y pipas de aguardiente, inmensas posesiones con la condición de respetarles los límites que se les trazaban, para que dentro de ellos pudiesen a su vez vivir y

${ }^{18}$ Subrayado del autor. 
conservar las cenizas de sus padres. Pero la.oleada de la población blanca llegaba en esto un poco antes o un poco después, y batiendo esa frontera tras de la cual se había recogido el indio, la demolía al primer combate, quedando éste expuesto a todo género de rigores. Acudía el infeliz al Estado, que no podía protegerle contra esta opresión. Apelaba al Congreso Federal, que con buenas palabras le remitía al Estado. No comprendiendo esta justicia de los blancos, recurría en fin a la justicia de los bosques, cometía represalias, que indefectiblemente atraía sobre sí los rayos del Capitolio y su ruina inevitable. Para esto ha mantenido y mantiene la Unión un pie de ejército de 10,000 hombres, encargados de acabar la obra comenzada por la más pérfida política. En esta guerra han cogido abundantes laureles, militares que como [Andrew] Jackson no han tenido escrúpulos en unirlos con otros más legítimos y más nobles cogidos en las líneas de Nueva Orleáns contra las huestes que vencieron a Napoleón. Díganlo sus [campañas] contra los semínolas de la Florida.

La Unión Americana tuvo desde luego que zanjar cuestiones de límites con las potencias europeas, señaladamente con Inglaterra y España, y estas cuestiones, que han sido el tema continuo de su diplomacia hasta el día, las ha resuelto siempre con multitud de trámites y de fórmulas, porque en ninguna parte se podrá encontrar un culto más farisaico de la letra, pero no igualmente respondiendo a esa voz de justicia interna, que parece debía dejarse escuchar de preferencia en el gabinete que preside a la nación más religiosa e ilustrada de la tierra, al menos según sus modestas pretensiones, y en que tan hondas huellas ha debido dejar al espíritu de Washington. Pero éste que será el tenor de nuestro próximo artículo, naturalmente nos conducirá a la guerra de México, y a los motivos políticos que la sostienen.

El Español, 24 de noviembre de 1847. 
LUTS MANUEL DEL RIVERO

\section{Artículo VIII}

Cuando la fortuna de las armas hubo coronado la justa causa por la que habían luchado con tanto denuedo las colonias inglesas de Norteamérica, si bien con el auxilio material directo de naciones tan poderosas como Francia y España, pensaron inmediatamente en consolidar su conquista por medio de tratados, y de asegurarse el inmenso territorio, que al Oeste de los mexicanos divisaba y había ya menester su nacionalidad vigorizada y alentada por los esfuerzos felices de la lucha de la independencia. Pusieron, pues, la mira en el gabinete de París, como el más propicio a su causa, con el fin de radicar allí una negociación general; pero bien pronto sus negociadores se convencieron de que aquel gabinete no secundaría sus designios, y que antes bien de acuerdo con España contrariaría, concertándose con ella para privarles de la región del Oeste a que aspiraban.

Trasladaron, pues, la negociación a Londres, y con aquel gabinete celebraron en 1783 un tratado provisional, en que Inglaterra les reconocía por límites, excepto el ángulo de Nueva Escocia, la cresta que divide las aguas del San Lorenzo de la de los ríos que caen en el océano Atlántico, hasta el origen del Connecticut, una línea al Oeste hasta encontrar con el San Lorenzo, y en igual dirección la línea media en este río, y de los Grandes Lagos hasta el de los bosques y nacimiento del Misisipí, que se suponía entonces estar en el paralelo de estos últimos lagos. Aseguraron, pues, toda la región al Sur de ésta ya inmensa línea, que luego extendieron por el paralelo $49^{\circ}$ hasta las montañas rojizas, arreglando al fin en época más reciente la ruidosa cuestión del territorio del Oregón y la del Noreste al otro extremo, de la manera que ya el público conoce.

Encontrándose sobre la costa del Noroeste en el Pacífico con los rusos, que no contentos con el Asia, salvado el estrecho de Behring, se habían derramado en América a lo largo de dicha costa; y en 1824, pactaron con el autócrata [el zar de Rusia] como límite de sus respectivos establecimientos en aquel punto el paralelo $34^{\circ}$ y $40^{\prime}$ Norte. Se ve, 
pues, que los Estados Unidos son previsores, y que a duras penas reconocen a lạs naciones europeas en América, donde sólo les conceden derecho de ciudadanía, mientras llega el momento de lanzarlas a todas de las que ellos reputan su propia casa y heredad patrimonial.

Pero les quedaban cuestiones más difíciles de arreglar hacia el Sur. Aquí se encontraron con España, precisamente en los momentos en que desde su cenit declinaba el astro de nuestra fortuna, y el suyo asomaba radiante en el horizonte americano. Por el tratado celebrado en 1795 y firmado por Godoy, ${ }^{19}$ reconocimos por límites meridionales en la república el paralelo $31^{\circ}$ Norte desde el Misisipí hasta el Apalachicola hacia el Este, la corriente de este río hasta su unión con el Flint, una línea al Este hasta cortar el Santa María, y el curso de este río hasta el Océano Atlántico. En consecuencia, les abandonamos un grado entero a que teníamos derecho por haber dado los ingleses, de quienes la habían conquistado, esta extensión de Florida Occidental, y con él las mejores tierras de aquella provincia en unión de algunos fuertes, incluso el de Natchez. Reconocimos los límites del tratado provisional de 1783 susodicho, y con esto sancionamos las ambiciosas miras de aquel gobierno. Les concedimos el derecho de libre navegación por el Misisipí y un depósito temporal en Nueva Orleáns del que provinieron grandes altercados. Por último, estipulamos con ellos el principio de que la bandera cubriese las propiedad enemiga en tiempo de guerra, de donde nacieron los 15 millones de

${ }^{19}$ Éste es el "Tratado de amistad, límites y navegación entre S.M.C. y los Estados Unidos de América; firmado en San Lorenzo el Real a 27 de octubre de 1795", apud, Alejandro del Cantillo, Tratados, convenios y declaraciones de paz y de comercio que han hecho con las potencias extranjeras los monarcas españoles de la Casa de Borbón desde 1700 hasta el día, 1843, Imp. de Alegría y Charlain. Tratado conocido como de San Lorenzo, que también concedió a los ciudadanos de los Estados Unidos el derecho a navegar por el río Misisipí, y la creación en Nueva Orleáns de un depósito que facilitara los transbordos marítimos. Vid, José A. Armillas Vicente, El Mississippi: frontera de España. España y los Estados Unidos ante el Tratado de San Lorenzo, 1977, Zaragoza, CSIC, Institución Fernando El Católico. 
duros, que con capital e intereses nos reclamaron y pagamos a la celebración del tratado de 1819 por presas hechas por nuestros cruceros y corsarios de propiedades americanas, o más bien inglesas cubiertas con el pabellón americano. Al propio tiempo que este pabellón no garantiza nuestra propiedad de ser apresada por los cruceros y corsarios ingleses, por haberlo estipulado así cuatro meses después del dicho Tratado de San Lorenzo el gabinete de Washington con el de Londres.

Sobre estos pretendidos perjuicios hicimos con aquel gabinete un convenio en 1802, en que reconocimos en principio la obligación de su resarcimiento; pero que no ratificó nuestro gobierno por graves dificultades sobrevenidas, a que no dio solución conveniente el americano, y por su empeño en no abandonar el punto del resarcimiento de las presas hechas a sus súbditos en nuestras costas y puertos por los cruceros y cónsules franceses durante la guerra: ambos puntos fueron liquidados en 1819 con la cesión de las Floridas, según veremos. ${ }^{20}$

Los Estados Unidos no se contentaban sin embargo, con las ventajas del tratado de 1795. Cada concesión que se les hacía, era, y ha sido para ellos hasta el día, el estímulo de una nueva demanda y el principio de otra nueva concesión. No les bastaba ya la inmensa región que al Occidente de los Apalaches se extiende hasta el Misisipí, entre los grandes lagos y las Floridas, ni la libre navegación de ese río que con la exclusión de los demás extranjeros disfrutaba: había menester por de pronto su inquieta ambición, no sólo el libre curso, sino el completo dominio de ese majestuoso río, cuya desembocadura no podían ver sin impaciencia en extranjeras manos. A tan importante adquisición se encaminó, pues, su activa política, y para ello, tanteada en balde la corte de Madrid, por último se dirigieron al gabinete de París, por quien aquélla era dominada. Mas en esto ocurrió un gran cambio.

Entre los gigantescos proyectos que por entonces rodaban en la cabeza del vencedor de Marengo, uno de ellos era un grande establecimiento colonial. Puso la mira para efectuarlo en la Luisiana, cuya retrocesión obtuvo de la dócil España por el tratado secreto de San

${ }^{20}$ Se refiere al Tratado Adams-Onís. 
Ildefonso de 1 de octubre de 1800 , celebrado entre las altas partes contratantes acerca del engrandecimiento del S.A.R. el Infante duque de Parma en Italia ${ }^{21}$ como si nuestros ministros no hubiesen tenido cosa mejor en qué pensar que en buscar reinos para los vástagos de la casa real. ${ }^{22}$ Pero nuestra corte se había puesto bajo la férula del primer cónsul, y sus votos más íntimos se satisfacían además con este soñado engrandecimiento. Lo que hay aquí de más curioso es, que después de entregarse, como se entregó, en cuerpo y alma nuestra corte a Napoleón hasta el punto de sacrificarle su política, sus tesoros, la flor de nuestro ejército, toda nuestra marina, y aun nuestro territorio, con evidente riesgo de nuestras colonias, que por sí solas se sostuvieron, todavía encuentran los historiadores franceses que no hicimos lo bastante por Napoleón, que nuestra alianza le era onerosa, y que él fue quien en todo tiempo y principalmente en Amiens, sostuvo los intereses de sus aliados aun más allá de sus compromisos. ¡Tan arraigada está entre ellos la idea de que España es un satélite de la Francia, y que toda veleidad de independencia es de su parte un crimen imperdonable!

Los negociadores americanos, fijos también en su idea llegan al fin con poderes tan sólo para comprar las Floridas y la isla [de] Nueva Orleáns, seguros de que hallarían coyuntura de colocar su dinero en medio de los apuros del erario consular. La fortuna les salía al encuentro, y en vez de la isla de Nueva Orleáns, se hallan con la oferta de toda la Luisiana, pues Napoleón había abandonado ya su favorito proyecto de colonización: oferta que no titubearon en aceptar, aunque

${ }^{21}$ Subrayado del autor.

${ }^{22}$ En efecto, el $1^{\circ}$ de octubre de 1800 se hizo la transacción a favor del duque de Parma, yerno de Carlos IV. Causa pasmo recordar los términos de los Preliminares de San Ildefonso. Napoleón en su calidad de Primer Cónsul de la República Francesa prometía al duque de Parma 1,200 almas en Italia y España, entregaba seis barcos y ¡la Luisiana! Posteriormente, el 21 de marzo de 1801, se firmó el convenio llamado de Aranjuez, que confirmaba la cesión de la Luisiana a Francia. Vid, André Fugier, "La Revolución Francesa y el Imperio Napoleónico", Historia de las Relaciones Internacionales, dirigida por Pierre Renouvin, 1960, Madrid, Aguilar, p. 911. 


\section{LUIS MANUEL DEL RIVERO}

excedía notoriamente sus poderes, cerrando el tratado en 15 millones de duros. El gabinete de Washington aprobó su conducta y los Estados Unidos se vieron no sólo dueños del codiciado imperio del magnífico río, sino con títulos a su inmensa región occidental. Debemos añadir que la corte de España protestó contra semejante venta, por haberse infringido con ella un artículo secreto de la retrocesión, en virtud del cual se obligaba al gabinete francés a no enajenar la Luisiana sin consentimiento del nuestro; pero tuvo que retirar la protesta y que pasar por esta nueva prueba de interés que le daba su generoso aliado. Este tratado, celebrado en 30 de abril de $1803,{ }^{23}$ realmente decidía la suerte de las Floridas, que ya quedaban cortadas de nuestro territorio, y daba un peligroso vecino a nuestras provincias mexicanas.

Con efecto, los americanos empezaron desde luego a plantear pretensiones fundadas en la soñada grandeza antigua de la Luisiana y cómo se había vendido en el estado en que la poseía España cuando la retrocedió, y en el que Francia la había poseído anteriormente, de aquí que aspiraron desde luego y pidieron a España les entregase juntamente con ella toda la orilla izquierda hasta el río Perdido, esto es, la Florida occidental, y toda la orilla derecha hasta el río Bravo, esto es, toda la provincia de Texas con parte de la Coahuila, por la sencilla razón de que España poseía al tiempo de la retrocesión juntamente con la Luisiana todo ese inmenso territorio, y por la no menos con-

23 "Los Estados Unidos habían visto con disgusto aquella instalación francesa, que disminuía seriamente sus esperanzas de extenderse hacia el gran Oeste [...] Jefferson encargó a su amigo Pierre Du Pont de Nemours que propusiera al Primer Cónsul algún arreglo honorable. Bonaparte no tenía más remedio que aceptarlo, ya que la guerra estaba en puertas, antes que Luisiana hubiera sido puesta en estado de defensa. Las negociaciones fueron llevadas en París por un [norteamericano] francófilo, Livingston, y por [James] Monroe defensor de la expansión hacia el oeste y de la navegación por el Misisipí. Con tal facilidad que dejó a los [diplomáticos] norteamericanos asombrados, consiguieron el tratado el 30 de abril de 1803, por el cual Francia vendía la Luisiana a los Estados Unidos por 60 millones de francos." Fugier, ref. cit., p. 1105. 
vincente de que algunos mapas antiguos apoyados en una concesión imaginaria de terreno hecha por Luis XIV, hacían confinar la Luisiana con Nuevo México y el río Bravo.

El gabinete español rechazó lleno de asombro tales pretensiones, que en realidad tenían por objeto abrir una negociación, en que se arreglase este punto en cambio de la reclamación de perjuicios pendientes y de algunas otras concesiones. El [gabinete] hizo ver que desde el siglo XVI y el descubrimiento de la Florida en 1512 por Juan Ponce de León, al que se siguieron otro y otros navegantes y capitanes, España se halló en quieta y pacífica posesión de todas las riberas del seno mexicano; quedando éste realmente convertido en un lago español, sobre todo desde que en 1562 fue hecho prisionero por el gobernador de la Ribaut en el fuerte de Charlesfort; que esta posesión no interrumpida había continuado hasta el establecimiento en el Misisipí y la Mobile de los franceses, que al mando de [Robert Cavalier de] La Salle bajaron desde el Canadá por dicho río, cuyo jefe dejada allí su gente vino a Francia, y con nueva expedición salió de la Rochela en 1684 para explorar las bocas del Misisipí; que el desgraciado La Salle equivocó estas bocas y en su lugar entró al Oeste en la bahía de San Bernardo, levantando un fuerte que al fin arrasaron los indios, mientras que él fue asesinado por sus compañeros en el interior, donde se había internado en busca de unas soñadas minas de plata; que en su consecuencia envió el virrey de México una expedición a aquella bahía para cerciorarse de la desaparición de los franceses, y en 1690 se fundó la primera misión de San Francisco de Texas, cuyo nombre, que en la lengua del país significa amigos, quedó a la provincia por haber saludado con él a sus indios y ser de ellos bien recibido el capitán de aquella primera expecición Alonso de León; que las misiones y la población de Texas se adelantaron y aumentaron hasta con familias canarias llevadas por el gobierno en el principio del siglo XVIII, quedando en fin constituidos tácitamente sus límites y dividida esta provincia de la Luisiana por el río Conecuh al Este del Sabina y una línea al Norte que pasaba entre los dos fuertes de las Adaes y de Natchitoches, 


\section{LUIS MANUEL DEL RIVERO}

situados a ocho leguas de distancia, el primero en el territorio español y el segundo en el francés.

Por el reglamento de presidios de 1772 quedó aquella provincia aún más defendida; pero como por entonces la Luisiana estaba en poder de España se desatendieron los fronterizos. En efecto, en la guerra con los ingleses había la Francia perdido varios territorios de la Luisiana, que incorporados con otros que cedió España formaron a la izquierda del Misisipí la Florida occidental, que el tratado de 1762 adjudicó a Inglaterra. En el año siguiente Francia cedió a España la Luisiana, o por indemnización de los perjuicios que le había causado el pacto de familia, o porque realmente no pudiese sostenerla; pero cedió la Luisiana que le quedaba después de la segregación de la Florida occidental, comprendida entre el río Conecuh al Oeste y al Este el Misisipí, el Aberville y los lagos Mauropas y Ponchartrain al mar; la misma Luisiana que retrocedió a Francia en 1800, la misma la compraron los Estados Unidos en 1803. Es cierto que España poseía en la última época la Florida occidental; pero era, igualmente que Texas, una provincia diversa, que había conquistado en 1780 con sus armas de manos de los ingleses, y que éstos le habían reconocido en un

178 tratado solemne.

Estaban, pues, destruidas de todo fundamento las pretensiones del gabinete de Washington; pero su política las mantenía vivas, porque se dirigía a ocupar las Floridas de una u otra manera, aprovechando cualquiera oportunidad. Presentósela el pueblo de los Estados Unidos, que tan admirablemente secundaba la política de su gobierno, como que ambos constituyen un cuerpo y una alma; ese pueblo conquistador a su manera, que envía por delante sus aventureros y sus agentes, a quienes siguen sus soldados y por último sus diplomáticos, los cuales vienen a protocolizar los títulos de su propiedad, saldando con sacos de dollars la cuenta de sangre y de independencia que tienen abierta a las naciones vecinas, porque no permita el cielo, que estos honrados mercaderes, descendientes de los honradísimos cuáqueros, dejasen de pagar hasta el último maravedí. 
Ese pueblo, pues, se ingirió en Baton Rouge, una de nuestras poblaciones de la Florida, y se promovió una revolución en aquel distrito; el cual usando de su soberanía, declaró, que no quería continuar viviendo bajo el imperio del rey de España, y que de su propia voluntad se unía e incorporaba a los Estados Unidos. El presidente tomó entonces posesión en 1810 en dicho distrito, y el ejército se fue adelantando y ocupando otros puntos bajo el pretexto, o de proteger los votos del pueblo, o de sustraer aquellas provincias al riesgo de caer en manos de potencias enemigas, pero todo bajo declaración que hizo en una proclama dicho presidente, "que perteneciendo aquellos territorios los de la Florida occidental a los Estados Unidos como parte integrante de la Luisiana, ${ }^{24}$ había tenido por conveniente ocuparlos, porque así lo exigía la justicia y la política; pero que quedarían en su poder, como lo estaba en el de España, sujetos a una amistosa negociación".

No podía exigirse más buena fe ni mayor lealtad de parte de una potencia amiga, que ya que tan pronto había olvidado la deuda de gratitud que debía a España por la sangre que derramó y tesoros que gastó en ayudarla a alcanzar su independencia, al menos manifestaba un seguro instinto en aprovechar el momento oportuno de herir a mansalva, aquél en que su aliada antigua estaba nada menos que con Napoleón entre manos ocupada en defender su independencia. La retribución era cumplida. Aun por esto y por más auxiliarla, se negó seguramente el gabinete de Washington a reconocer como ministro al señor [Luis] de Onís, que ya desde 1809 había sido enviado a aquel gobierno por la Junta Central, ni lo quiso reconocer hasta la paz general de 1812, diciendo: "que aunque aplaudía los esfuerzos de los españoles en su gloriosa lucha, no podía reconocer ministro alguno de los gobiernos provisionales de España porque la Corona estaba en disputa y la nación dividida en dos partidos y que hasta la decisión de esta lucha los Estados Unidos se mantendrían neutrales, como simples espectadores". Seguía, pues, su política que iremos viendo desarrollarse.

El Español, 26 de noviembre de 1847.

${ }^{24}$ Subrayado del autor. 


\section{LUIS MANUEL DEL RIVERO}

\section{Artículo IX}

No repruebo en los Estados Unidos su acción grandiosa sobre la suerte de la humanidad entera, en lo que miro algo de providencia; pero sí repruebo los medios de que su política se sirve muchas veces para forzar y extremar esa misma acción, que no quisiera ver tan a menudo desbordar el cauce de la razón y de la justicia. Acaso me olvido de que la acción humana, por ser colectiva y partir de un gran foco nacional, no es menos ocasionada que la individual a impregnarse en las pasiones y sacudir el yugo de la razón: acaso sea una ilusión generosa la esperanza de ver algún día una gran política unida con una gran moralidad; pero creía que un pueblo tan nutrido de ideas y de hábitos racionales como el de los Estados Unidos, era digno de inaugurar en el mundo ese raro fenómeno y de alegrarle con el espectáculo de esa sublime novedad. Con sentimiento debemos renunciar a esa consoladora creencia: la democracia de los Estados Unidos es como todas las conocidas hasta el día: insolente en sus deseos, ingobernable en su prosperidad, expuesta a perecer como todas, por sus propios excesos, aunque de una probable duración mucho más extensa, porque excede a todas en la dificultad y grandeza de la tarea que se le ha confiado, en la trascendencia del papel que desempeña en el mundo. El gobierno ya debiera contenerla en provecho de su misma gloria y permanencia, partícipe de todas sus pasiones de que se convierte en instrumento ciego, y tiende a precipitarla.

Hémosle dejado ya en posesión de la Luisiana y las Floridas; faltando para alcanzar este último resultado a los deberes de la justicia y a los de la gratitud; empleando medios de que se avergonzaría un particular honrado; calumniando, en fin el noble heroísmo de una nación amiga, que se levanta como un solo hombre para repeler la invasión extranjera, por la necesidad de encontrar un pretexto con que cubrir sus tortuosas miras al negarse a reconocer al ministro de su gobierno, del mismo que mandaba en México, que era con quien tenía relaciones de vecindad. 
Pues bien, de esta posición ambigua y favorable se sirvió aquel gobierno para dar vuelo a la usurpación que ya meditaba de las provincias mexicanas. Tiempo había que los Estados Unidos eran el cuartel general de todos los descontentos de la América española, el foco de todos los planes de conspiración, de sangre y de trastorno que se fraguaban contra aquellas pacíficas y felices posesiones. Aun hacía más todavía; aquel gobierno había despachado emisarios a todas partes para conocer a fondo las localidades, los recursos, las ideas y costumbres; para tantear el terreno. Las autoridades españolas de ordinario no sospechaban de estas gentes, a menos [que] su aparato y descaro les hiciesen tomar providencias, como sucedió en 1805 con la expedición a las Provincias Internas de México del teniente Pike, ${ }^{25}$ oficial del ejército americano, que en unión de algún soldado del mismo ejército, se presentó a explorar el país, de donde fue expulsado.

Por los años que vamos corriendo de 1810,1811 y sucesivos, los emisarios americanos se unieron con los franceses para soplar en México el fuego de la revolución; sea que Napoleón desesperarse ya del trono de España o que quisiese promover a las fuerzas con que allí combatía una diversión poderosa en América. Ese fuego prendió, causando los horrores y devastaciones sin cuento de que por primera vez desde la conquista se vio plagado el suelo de México. De los Estados Unidos salían buques, expediciones y armamentos que tenían por objeto auxiliar a los disidentes en México con todo género de recursos: la Luisiana era el paso de estos aventureros, armados y equipados hasta el número a veces de setecientos hombres que iban a esparcir el terror en aquellas provincias, y de donde ordinariamente volvían batidos y perseguidos por las tropas del virreinato, pero para rehacerse igualmente que los cabecillas en la insurrección, y volver con nuevos bríos a hostilizar aquel país. Ésta era la vecindad que teníamos en los Estados Unidos; éstos los generosos procedimientos

${ }^{25}$ Zebulón Montgomery Pike. Oficial del ejército estadounidense. A principios del siglo XIX penetró en Nueva España y fue detenido y enviado como prisionero a Santa $\mathrm{Fe}$ y luego a Chihuahua, para ser finalmente liberado. 


\section{LUIS MANUEL DEL RIVERO}

que merecíamos a su gobierno, el cual interpelado por nuestro digno y celoso ministro el señor de Onís, aun antes de ser reconocido con carácter oficial, y aun cuando se le señalaban las personas, el lugar de las reuniones y los armamentos, respondía con evasiones, y no tomaba medidas bastantes para contener un tal desbordamiento de injurias y tropelías.

A tal punto llegan éstas, que desde 1815 se organizó en varios puertos, y señaladamente en Baltimore, un sistema de piratería, saliendo de ellos con bandera de los disidentes multitud de corsarios que volvían cargados con los despojos del comercio español, cuyos cargamentos eran declarados buena presa por los tribunales de la federación. Cuando se interpelaba al gobierno por tales excesos, así como por el de permitir entrar y salir en los puestos a los disidentes con su bandera, contestaba que el sistema de los Estados Unidos era no mezclarse en las cuestiones de España con sus provincias americanas, y permanecer neutral en esta lucha, añadiendo que los administradores de las aduanas tenían orden de admitir toda bandera con tal que el buque pagase los derechos y respetase las leyes establecidas. Esto parecería increíble si no lo afirmase un funcionario tan respetable e ilustrado

182 como el señor de Onís, en la Memoria que escribió para ilustración del tratado de $1819 .^{26}$

A pesar de tan inicuo tratamiento, España llena del honor y de la buena fe que siempre ha procedido en sus relaciones exteriores, estaba dispuesta a celebrar un tratado de límites favorable a los Estados Unidos, en que además se arreglase satisfactoriamente la cuestión de reclamaciones pendientes desde la convención de 1802, y otras que habían sobrevenido. El gabinete de Washington que había diferido el reconocimiento de nuestro ministerio desde fin de 1809 hasta la paz general de 1815, no pudo o no juzgó ya conveniente resistir a estas nobles instancias del gobierno de Madrid, y en 1816 se comenzó en

${ }^{26}$ Luis de Onís, Memoria sobre las negociaciones entre España y los Estados Unidos de América, que dieron motivo al tratado de 1819, con una noticia sobre la estadística de aquel pais, 1826, México, Martín Rivera. 
Washington la negociación que con mil dificultades y tropiezos dio al fin por resultado el tratado de amistad, arreglo en diferencias y límites firmado en 22 de febrero de 1819.

El gabinete aquél se hallaba ya probablemente desilusionado acerca de la pronta emancipación de México, y aplazando sus esperanzas tuvo que aceptar a duras penas la cuestión de límites en que principalmente insistía el de Madrid. No tenía además motivo para estar satisfecho del estado de cosas producido por la revolución mexicana, que en último resultado era sólo favorable a las mercaderías inglesas, cuyos arrieros eran de los Estados Unidos. Estas mercaderías con efecto invadían por todos puntos el continente americano, abriéndose paso a este mercado por toda clase de vías. España había relajado en el particular de su antigua rigidez, y dejaba sobre las puertas abiertas o mal guardadas a este comercio, con la mira de conciliarse siquiera la neutralidad de Inglaterra en la lucha que traía con sus antiguas colonias; pero Inglaterra como Francia, como toda Europa sostenía la causa de la insurrección con su influencia moral, con armas y recursos, aunque nunca de una manera tan desacertada como los Estados Unidos. Inglaterra y Europa se han llevado el chasco y el castigo que tenían merecido: hoy recogen el fruto de las semillas de rebelión que entonces esparcieron, y aunque tarde, se habrán apercibido de que nunca se violan impunemente las leyes del mundo moral, y la primera de todas ellas la justicia; de que la pretendida soberanía nacional cuando no va ligada con la de la razón, no es más que la soberanía del número, la pura y simple proclamación de la fuerza, que siendo la negación de todo derecho y de todo principio, no sólo es incapaz de regir el mundo moral, sino que es una nueva caja de Pandora, que con el sonoro título de revolución, va plagando la tierra de robos, infidelidades y asesinatos, de males y devastaciones sin fin, y extinguiendo en ella el reino de las razones, de la virtud. Los Estados Unidos recogerán también el fruto de su conducta.

Ellos habian hecho un comercio sumamente lucrativo, y multiplicado sus fuerzas productivas a favor de las guerras del gigante, en que la revolución francesa había envuelto el mundo entero de Occidente. 
La política de neutralidad, que con tanto valor como previsión había defendido y hecho triunfar en su patria el inmortal Washington, era no sólo justa, sino provechosa en alto grado. A su amparo pudieron la marina y el comercio de Norteamérica tomar el rápido y asombroso vuelo, que los ha colocado ya tan cerca de su rival; y las mismas infinitas restricciones que entonces sufría el tráfico, y que agravó el bloqueo continental, fueron causa principal de que naciese la industria americana, y de que posteriormente se haya ido desenvolviendo a pesar de la mentida protección del llamado sistema protector, que también por allá domina, y da de sí bien amargos frutos.

Cuando en 1815 la lira de la paz vino a alegrar el mundo y hacer cesar hasta en la patria de Washington el derramamiento de sangre, sólo los Estados Unidos se entristecieron porque vieron disminuirse los inmensos provechos que la guerra les había traído y cercenase su navegación, su comercio y aun su industria. La revolución de la América española, siempre que habían fundado magníficas esperanzas, no les producía más que tristes desengaños, revueltos con un deshonor infinito. Veían con dolor que estaban trabajando por su odiosa rival [Gran Bretaña], la única nación que ellos no desprecian, la única que aborrecen de muerte. Todo esto pudo inducirles a tratar de límites con esta España pobre y desventurada, pero rica de honor, de nobleza y de porvenir.

El tratado de 1819 fue un acto político de nuestra parte, y honra a su hábil negociador, que no sólo tuvo que entenderse con el secretario de Estado, sino que habérselas con toda una prensa desenfrenada, la prensa de los Estados Unidos, en cuestiones de interés doméstico. El dio cara a ese torrente con gran valor, e hizo escuchar en todas partes la voz de la justicia. Los Estados Unidos pretendían, aunque sin viso de fundamento, tener títulos a la Florida Occidental; pero como mientras llegaba el momento de un amistoso arreglo, se había apoderado su gobierno de Baton-Rouge, de la Mobile, de Panzacola, y en fin, de las principales plazas de ambas Floridas, y el gran pueblo se había además apresurado a tomar posesión de esta nueva lotería, su restitución era imposible y además perjudicial, porque cercadas, excepto 
por el mar, de territorio americano, y separadas por la Luisiana de nuestras provincias mexicanas, hubieran sido perpetuamente en nuestras manos una manzana de discordia. Cediéronsele, pues, en cambio de los 15 millones de duros que reclamaban por los perjuicios pendientes de la convención de 1802, procedentes de presas hechas por nuestros cruceros o los franceses en la costa y puertos de España, cuya deuda tomaban sobre sí los Estados Unidos hasta la suma de 5 millones (a que calculaban se reduciría después de liquidada), obligándose a entregar copia de las liquidaciones y pagas, a fin de que el gobierno español hiciese valer su derecho, sobre todo las procedentes de las presas francesas.

Aparte de otras menores ventajas, y de la general de extinguir mil motivos de desavenencias, el principal fruto de este tratado fue para nosotros el que los Estados Unidos renunciasen a sus pretensiones siempre sobre Texas que por más exageradas que fuesen, hubieran hallado ocasión de hacerlas valer, como desgraciadamente lo han logrado después. Fijáronse, pues, nuestros límites con los Estados Unidos en el río Sabina, que desemboca en el seno mexicano, y su orilla derecha hasta el $32^{\circ}$ Norte, una línea al Norte hasta cortar el [río] Rojo de Natchitoches: el curso de este río hacia el Oeste hasta el $100^{\circ}$, longitud occidental de Londres, una línea al Norte hasta Arkansas; el curso de este río hacia el Noroeste hasta su nacimiento, y desde aquí el paralelo $42^{\circ}$ Norte hasta el Pacífico. Quedaban, pues, nuestras provincias de Texas, Nuevo México y Alta California, ampliamente dotadas y garantizadas. Las porciones imaginarias de esta inmensa línea debían ser trazadas sobre el terreno por una comisión mixta, que por las vicisitudes sobrevenidas no llegó a reunirse, y en que los mexicanos se han descuidado después, aunque diversas veces se haya ordenado su ejecución. El tratado, aprobado y ratificado, después de muchas dificultades vencidas en fin de 1820 por la corte de Madrid, lo fue igualmente por el gobierno de los Estados Unidos, quedando como ley del Estado en ambos países.

El teatro de la política americana se cambió en esto, y se trasladó a México por consecuencia de la emancipación de aquella colonia. La 
nación española no es ya para aquella política, sino una de tantas del viejo mundo, gastada y degenerada, y no merecería su atención si no estuviese destinada a servirle de cebo en lo poco que le resta que recoger de su pingüe herencia en el nuevo. La isla de Cuba no puede continuar bajo el absurdo y despótico mando del rey de España: aque1los virtuosos ciudadanos abominan este yugo y tienden sus brazos al gran pueblo, que tiene el encargo de lo alto de destruir todas las tiranias de la tierra, y no puede menos de dispensarle el favor de recibirles en su seno. Hay otros argumentos no menos poderosos que oponer a los viejos pergaminos del rey de España. Esta preciosa isla cuya punta occidental casi se da la mano con Yucatán y por el Norte se mira con la Florida, cierra el seno, que siendo ya un lago norteamericano, exige para su comodidad y su defensa la posesión de esta llave de oro; y así como los Estados Unidos adquirieron a Nueva Orleáns para completar la posesión del gran río, así adquirirán a Cuba para redondear la posesión del gran lago, que si no quedaría abierto a Europa por esta puerta. La prensa norteamericana ha planteado ya la cuestión en estos términos y ha dicho: "Cómprese Cuba al rey de España." Ellos la tomarán de un modo u otro, en la primera coyuntura que se presente y que no tardará en ofrecerse en este período de deshielo que aún no ha pasado para nosotros; pero la tomarán con su cuenta y razón, porque son demasiado ricos para codiciar el bien ajeno, demasiado buenos protestantes para quedarse con el sudor de su prójimo.

Mas aún tardará esto un poco, por estar en el día los Estados Unidos muy enredados en México; no basta conquistar la capital, es necesario dominar el país; esto también lo lograrán porque su partido es muy grande en él, y lo que no acaben los rifles bien pueden allanarlo los dollars en un país tan desorganizado; pero la más difícil empresa es poner un poco de orden en medio de este caos, galvanizar este cadáver para que funcione un cuerpo de nación, mientras llega el gran pueblo que todavía se encuentra a algunas jomadas, y pueda entonces impunemente enterrarse.

Este resultado ha producido las felices intrigas de los diplomáticos de la Unión. Siendo de los primeros a reconocer y tratar en México 
después de la caída del imperio, su influencia en un pueblo nuevo, exaltado por su feliz y mágica emancipación, fue tan pronta y devastadora como lo es la de un tizón aplicado a un montón de combustibles secos. Ella, parece al menos por las muestras, se propuso en este grande incendio consumir todo entero el elemento español, único capaz de dar consistencia separada a aquella sociedad y de resistir la asimilación intentada desde un principio por la sociedad anglosajona del Norte. Como ese grande elemento mantenía trabados los heterogéneos elementos de que contaba aquélla, su aniquilación producida por la acción unida de la revolución y de las diplomáticas intrigas, ha producido la completa disolución social de México. La obra de asimilación, no de aquella sociedad que para nada necesitan y que les es antipática, sino de algunos de sus elementos y en especial de su territorio, es ya más hacedera para los Estados Unidos, que encontrarán sin embargo en esta coronación de sus hercúleos trabajos de medio siglo el principio de su castigo. Fáltame para completar este cuadro decir algo sobre la guerra de Texas.

El Español, 1 de diciembre de 1847.

\section{Artículo X}

Los límites de la provincia de Texas quedaban modificados por el tratado de 1819, sólo en la parte fronteriza de los Estados Unidos, con los que confinaba al Este y al Norte por el río Sabina y Rojo de Natchitoches, guardando los que de antiguo tenía con Nuevo México, Chihuahua y Coahuila. Estas provincias, con las de Nuevo León y Santander [Tamaulipas], se habían comenzado a colonizar desde fines del siglo XVI; pero Texas no lo fue hasta el año de 1690, con ocasión del establecimiento de los franceses de la Mobile, Luisiana y aun en la bahía de San Bernardo, de que llevamos hablando. A principios del siglo XVIII se continuaron estableciendo misiones y presidios que formaban otros tantos centros de población a donde el gobierno pro- 
curaba enviar familias de varios puntos, y en especial de las Canarias, desde 1772 se mejoraron los presidios, y recibió nuevo impulso la provincia con la vecindad de la Luisiana que había venido a nuestras manos por el tratado de 1764 , y con la cual se había estado frecuentemente en guerra, habiendo hecho durante la regencia del duque de Orleáns los franceses de la Luisiana, una incursión hasta San Antonio de Béjar, que fue dichosamente rechazada por el marqués de Aguayo.

Sin embargo, de estos estímulos, la provincia progresaba poco en población y cultivo, ya por su excentricidad, ya por las dificultades que ofrecía su suelo cortado de innumerables corrientes, ya principalmente por la vecindad de los indios, y a los cuales era dificil traer a raya. Sólo el celo de nuestros misioneros, algo más puro que el de los leñadores y cazadores que el pueblo de los Estados Unidos envía delante de sí para abrirse paso por entre las selvas, los célebres pionneers, podían luchar con tamaños obstáculos, regando con su sudor y su sangre el suelo que conquistaban para la civilización cristiana. Texas tuvo además mucho que sufrir con la guerra de independencia, siendo continuo teatro, sobre todo en los primeros años de las incursiones de los aventureros yanquis, que robaban, quemaban y asesinaban.

La colonización, pues, continuaba allí muy en mantillas, habiendo sólo progresado en San Antonio de Béjar y Bahía de Goliad sobre el río de aquel nombre; país sumamente fértil y pintoresco, donde se había introducido un cultivo sumamente esmerado; cuando en 1821 las cortes españolas hicieron al ciudadano Moisés Austin de Misuri, una gran concesión de tierra en el centro de Texas con obligación de colonizarlas con trescientas familias católicas. Vuelto a su país y enganchadas las familias, se preparaba Austin a transportarse a su destino, cuando murió repentinamente, dejando empero como en legado este proyecto a su hijo Esteban, que lo planteó con gran resolución, pidiendo primero la rehabilitación de sus títulos al gobierno de Iturbide, que se los confirmó igualmente que los [gobiernos] que le sucedieron.

San Felipe de Austin sobre el río Brazos fue el centro de esta colonización norteamericana, que inmediatamente progresó y fue extendiéndose considerablemente a derecha e izquierda, favorecida 
singularmente por el espíritu público en los Estados Unidos, donde al punto se comprendió su inmensa importancia, y alentada también por nuevas concesiones y privilegios por parte de México. Entre éstos debe contarse el de introducción de esclavos por tierra, a pesar de hallarse prohibida por las leyes, las cuales habían declarado que todo hombre nacería libre en el territorio de la República. Se permitió, pues, esta introducción, que los colonos de Texas creyeron indispensable para desbrozar aquel terreno y reducirlo a cultivo, y éste fue un nuevo e inmenso aliciente para la emigración siempre ascendiente de los estados del Sur de la Unión, que desde entonces abrieron al nuevo estado un crédito indefinido en hombres y dinero.

Texas, que se presta admirablemente a todo género de cultivo; donde se coge el trigo, el maíz, el tabaco, el té, el café, la cochinilla, el añil, y sobre todo el algodón con una fecundidad y finura superiores a las mayores de los Estados Unidos, saldaba su cuenta con estas ricas producciones, y en especial con la última. Ofrecía además otros muchos alicientes a la emigración, su posición admirable sobre el seno a donde desembocaban sus hermosos ríos el Sabino, el Trinidad, el San Jacinto, el Brazos, el Colorado, el San Antonio, el Nueces, navegables todos por el vapor, algunos hasta 400 millas de su embocadura, y formando grandes bahías y puertos; su vecindad con los Estados Unidos, fuente para ella de vida, así como escudo de seguridad y de defensa; la abundancia de sus pastos naturales, donde se crían innumerables ganados, sin más industria de parte del hombre que la de marcarlos para recogerlos cuando están en disposición de serle útiles, y la no menor de excelentes maderas de construcción; la riqueza, en fin, de sus minerales, en especial del carbón de piedra y del fierro; todas estas circunstancias y ventajas hacían de Texas una preciosísima adquisición para los Estados Unidos, que empiezan a admirarla con predilección maternal, y a encontrarla desde luego como una extensión natural de su territorio, que se aumentaba así con 165,000 millas cuadradas de superficie, y daba una gran preponderancia a los estados del Sur, poseedores de esclavos. 
Texas por otra parte no pensaba en sacudir el yugo de la metrópoli, y gozaba sin gran ruido de su naciente prosperidad, cuando en 1829 comenzaron a turbarse sus buenas relaciones con el gobierno general, y fue con esta ocasión.

Durante las revueltas porque había pasado ya la República, se había distinguido el ministro Poinsett por sus íntimas relaciones con el partido yorkino, y naturalmente había irritado contra sí al partido escocés, en que se afiliaba la parte más sensata de la nación, la más amiga del orden; pero ahora irritó contra la ambición de los Estados Unidos y su ministro al saber que éste, prevaliéndose de los apuros en que la expedición de Barradas encontraba al erario, y encontrando con el apoyo del célebre [Lorenzo de] Zavala, yucateco ambicioso que tenía inmensas concesiones de tierras en Texas y deseaba hacerlas valer, había planteado cerca del gobierno de México la negociación de cesión de esta provincia; negociación descubierta y grandemente secundada por la prensa de los estados del Sur de la Unión. El presidente [Vicente] Guerrero, obedeciendo a este impulso de la opinión, no sólo no dio cara a esta negociación, sino que alarmado por los progresos de la colonización texana, y deseando popularizarse por todos los medios posibles, dio un decreto en el mismo año aboliendo la esclavitud en toda la República; medida que hería de muerte a aquella colonización, que tenía por base el cultivo por esclavos. Y llevando aún más lejos su hostilidad hacia los Estados Unidos, igualmente que hacia España, entró en relaciones con el presidente de la República de Haití a fin de promover una sublevación de negros en Cuba, y de extender en aquella poderosa nación la propaganda abolicionista.

En esto el general Santa Anna, niño mimado de la fortuna, acababa de ser por ella favorecido con la rendición de aquella desventurada expedición, y de ser en consecuencia elevado al rango de héroe de Tampico, que le acercaba bastante al solio dejado vacante por Iturbide. Este ídolo del día pidió la destitución de Zavala, su personal enemigo, que más tarde y arrojado de su patria, tomó parte activa en la revolución texana y murió ciudadano del nuevo estado. El gobierno tuvo que pedir al gabinete de Washington el relevo de su inquieto ministro 
[Poinsett]; y habiendo, en fin, caído por consecuencia del Plan de Jalapa en manos de Bustamante y su entendido ministro [Lucas] Alamán, doblemente alarmado en las pretensiones de los Estados Unidos, dio en abril de 1830 un decreto prohibitivo de toda ulterior emigración de los norteamericanos. Era ya demasiado tarde, y desde entonces adquirió nuevos tratados de fuerza esa emigración en Texas.

El odio de razas y de nacionalidad comenzó, pues, a envenenar las relaciones antes amistosas entre Texas y México: otras causas particulares contribuyeron a exasperarlas. Texas en unión con Coahuila formaban, según la Constitución de 1824, uno de los estados de la federación. Este régimen, el más análogo a los intereses de Texas, porque era el que más descentralizaba el poder, no lo era tanto que no diese motivo a mil disgustos y vejaciones. Su legislatura se hallaba fuera de su territorio a la derecha del [río] Bravo en Monclova, y en ella no figuraban sus diputados sino como una misión insignificante. Tenía que acudir al mismo punto para el despacho de sus negocios administrativos y judiciales, y todo esto sobre perjudicarla, la humillaba. Sin embargo, todavía por este tiempo su ambición no se extendía a más que a obtener alguna reparación en sus intereses lastimados, y mayor participación en el poder del Estado. Pero cuando realmente subieron de punto sus quejas y sus agravios, fue con motivo del movimiento reaccionario que en 1834 echó por tierra a la federación; a consecuencia del Plan de Zabaleta y perfidia del general Santa Anna hacia el partido democrático que lo había entronizado; de cuyos manejos provino el gobierno central que despojaba a los estados de su soberanía, y los sometía a los mandarines que con título de comandantes generales y de prefectos les enviaba México.

Texas aborrecía de muerte este gobierno, y desde luego se pronunció en favor de la federación, y se asoció al movimiento que en este sentido, y con el inmediato fin de echar abajo la administración de Bustamante promoviera en principios de 1834 el general Santa Anna, cuyo movimiento pasando por sus puras manos vino a parar a los dos años en el reverso del punto de partida, esto es, en el centralismo, en que se interesaban el clero y altas clases de México, según va dicho. 


\section{LUIS MANUEL DEL RIVERO}

Pero ya para entonces se encontraba Texas con las armas en la mano. El gobierno de Bustamante, previendo un conflicto, había enviado tropas de México que empezaran a guarnecer algunos de sus abandonados presidios y fortalezas. A principios de 1832 estas fuerzas diseminadas por el país ascendían a unos 1,300 hombres. Con ellas había penetrado en Texas el elemento militar, que traía inquieta y desorganizada la República, pues no puede haber en el mundo ejército más propio que el mexicano para vejar a su propio país ni menos apto para defenderlo de los extraños. Los norteamericanos de Texas, que no entendían de semejantes medios de gobierno, en los primeros días de 1832 se sublevaron contra el fuerte de Anáhuac sobre el Trinidad, cuyo comandante había aprisionado algunos paisanos obligándoles a restituírseles. Los colonos del río Brazos, a la primera noticia del levantamiento de sus hermanos, resuelven correr a su defensa; mas entonces llega la noticia del pronunciamiento de Veracruz, que aceptan en el momento no sólo por amor de la federación, sino por odio de la administración de Bustamante, y empiezan por atacar y tomar, no sin resistencia el fuerte de Velasco. Santa Anna despacha en el verano una expedición a la desembocadura del Brazos, para

192 cerciorarse del espíritu de la sublevación. Los colonos persuaden al coronel Mejía, que su objeto no era otro que el de servir la causa de la federación, a la cual siempre se les encontraría fieles, y la expedición vuelve a Veracruz con estas seguridades, conduciendo la guarnición del fuerte de Velasco. Los colonos de las inmediaciones del fuerte de Nacogdoches, imitan a sus hermanos del Trinidad y del Brazos, y en fin del verano de 1832, ya no había un soldado en la parte de Texas ocupada por los norteamericanos. Las aduanas siguieron la misma suerte, y el país quedó enteramente abierto a la emigración, al comercio y a los esclavos en la Unión, cuyos estados del Sur desde luego amenazaron agitarse y aprontar todo género de recursos para socorrer a sus hermanos de Texas en la guerra de independencia ya inminente.

En fin de este año se reúne en San Felipe de Austin, una convención de todo el pueblo texano, que redacta una Constitución del Estado de Texas, y acuerda una petición al gobierno de México para su separa- 
ción del de Coahuila: a esto se extendían aun por entonces sus deseos. Esteban Austin, fundador de la colonia, es despachado con esta misión a México; pero sus votos no son oídos por aquel gobierno, y entonces escribe una carta al ayuntamiento de [San Antonio de] Béjar aconsejándole organizar pacíficamente una administración local. Béjar era una antigua población española, y sus habitantes no favorecían las miras de los colonos: su ayuntamiento, pues, entregó la carta a las autoridades mexicanas, lo que produjo la prisión de Austin a su regreso para Texas. Más tarde escribe todavía desde la prisión, recomendando a sus paisanos las vías legales; saliendo de ella a tiempo de tomar parte con ellos en la lucha de la independencia, los auxilió con efecto con sus luces en el consejo y buenos oficios cerca de los Estados Unidos.

Las cosas permanecían en este estado, y los texanos continuaban sirviéndose de la bandera de la federación, cuando un incidente vino a precipitar la lucha. La legislatura de Monclova decretó para subvenir a sus gastos y los del gobierno federal la venta de 411 leguas cuadradas de tierras en Texas a unos especuladores texanos. El gobierno general anuló este decreto a pretexto de inconstitucionalidad, y realmente para quitar este alimento a la emigración de los Estados Unidos. Comisionó, pues, al general [Marín Perfecto de] Cos, para que expulsase la legislatura rebelde. Hízolo éste al pie de la letra, y los diputados texanos se restituyeron a su patria, proclamando la rebelión abierta.

Los texanos respondiendo al llamamiento, levantaron este estandarte en noviembre de 1835, en las mismas llanuras de San Jacinto, donde ocho meses después había de sancionarse su independencia por una completa victoria. Formóse un gobierno en San Felipe con el nombre de comisión de seguridad pública, bajo la presidencia de Esteban Austin, y comenzó desde luego la lucha de que hablaremos en un próximo número.

El Español, 7 de diciembre de 1847. 
LUIS MANUEL DEL RIVERO

\section{Artículo XI}

El primer socorro remitido de Nueva Orleáns fueron 7,000 duros y dos compañías de aventureros, quedando el meeting en correspondencia con la comisión de seguridad, para los envíos que se fueran sucediendo. La guerra de Texas, sumamente popular en los Estados Unidos, no solamente atraía a gente baldía del Oeste, sino a sujetos muy principales, que realmente la organizaron y dirigieron.

Animados, pues, y llenos de ardor los voluntarios de Texas, apenas se habían reunido sobre el Guadalupe en informes pelotones cuando a principios de octubre de 1835 se lanzan sobre el enemigo dirigidos por los más valientes de entre ellos, toman por asalto el fuerte de Goliad, vencen en pequeños encuentros, y obligan al general Cos a encerrarse en San Antonio de Béjar con fuerzas superiores y mejor organizadas. Al otro extremo, y en los confines de los Estados Unidos, los voluntarios se ponen en marcha hacia el teatro de la guerra bajo la conducta del norteamericano Samuel Houston, célebre por sus aventuras, que ya desde 1830 se había fijado en Texas, atraído acaso por el presentimiento de su destino, y acompañado de la fama de venir a revolucionar el país. Pero al mismo tiempo Zavala sucede a Austin en la presidencia de la comisión de seguridad.

La consulta general de Texas se reúne en San Felipe el 3 de noviembre, y organiza un gobierno provisional en esta forma: [Ashbel] Smith, gobernador en competencia de Austin, que pasa con una misión a los Estados Unidos, [Samuel] Houston, general en jefe del ejército. Da también un manifiesto en que sólo se enarbola la bandera de la federación que acababa de derribar en México el general Santa Anna, y ofrece el auxilio de Texas contra el enemigo común de los estados que quieran combatirle. En fin, se disuelve el día 14 aplazándose para el $1^{\circ}$ de marzo próximo, después de redactar una sucinta Constitución, en que al lado del jurado se reconoce por siempre la esclavitud, pero con la condición de que los esclavos sólo habían de ser importados de los Estados Unidos. 


\section{LA GUERRA DE MÉXICO}

Entre tanto el sitio de [San Antonio de] Béjar continuaba sin aprestarse mucho, los voluntarios desmayaban con la tardanza, y con los rigores de la estación lluviosa; el coronel Burlesson que los mandaba, había dado la orden de retirada para el día 4 de diciembre; pero en esto se presenta un desertor de la plaza que certifica la mala disposición de la tropa. Reúnense entonces los más valientes bajo el mando de uno de sus héroes, acometen con resolución el día 5, logran penetrar y establecerse dentro de la plaza, y al cabo de cuatro días de incesante pelea conquistan el terreno a palmos y se apoderan del fuerte, permitiendo al general [Marín Perfecto de] Cos y sus oficiales retirarse bajo palabra de honor de no hacer armas contra la federación. Así, a los tres meses y medio de haber alzado el grito de rebelión en las llanuras de San Jacinto, no quedaba un solo soldado mexicano en todo el territorio mexicano.

Con tan prósperos sucesos sube de punto el entusiasmo así en Texas como en los Estados Unidos; lo cual unido al progreso del odiado centralismo en México, hace nacer el deseo general de una completa independencia. Este deseo después de muchas excitaciones, se formula en fin, y la convención nacional reunida el primero en Washington sobre el Brazos, declara la independencia de Texas el día 2 de marzo de 1835. La convención publica una sucinta Constitución, y reorganiza el gobierno en que entra [Lorenzo de] Zavala de vicepresidente.

Santa Anna, sofocada la última revolución federal con la toma de Zacatecas, y faltándole para coronar sus triunfos dar cima a la nacional empresa de abatir a sus pies al orgulloso yanqui, con el mayor ejército que pudo [reunir] se había presentado ya el 21 de febrero delante de Béjar, cuya ciudadela se rindió al cabo de quince días de heroica resistencia, siendo pasada a cuchillo su pequeña pero valiente guarnición con el bizarro Travis a su frente.

Al propio tiempo cae el fuerte de Goliad, en manos del general mexicano Urrea, quien con triple fuerza persigue a su guarnición de quinientos hombres, y después de encarnizados combates la fuerza a entregarse bajo capitulación, con su jefe el coronel Fannin. Esta capitulación, que después se ha negado, fue hollada y con ella los santos 


\section{LUIS MANUEL DEL RIVERO}

fueros de la humanidad, por el general en Jefe que dio la orden de fusilar a los trescientos prisioneros; conducta bárbara que lejos de producir el calculado desaliento, llevó a todos los corazones texanos el furor de la venganza, y acabó de empeñar al país en la causa de su independencia.

El ejército mexicano avanza en tres cuerpos, llevando el del centro al general en jefe. Houston, que apenas había tenido tiempo para mal organizar sus fuerzas, abandona la línea del Guadalupe y se retira hacia las fronteras de los Estados Unidos, aproximándose otro tanto a la base de sus operaciones, cuando Santa Anna se alejaba de la suya, si bien a costa de sacrificar los establecimientos texanos, y entre ellos el principal San Felipe de Austin; esta ciudad de unos 6,000 habitantes con los alrededores, fue quemada por sus propios hijos al refugiarse en los montes.

En fin Houston, reconcentradas sus fuerzas, se detiene en San Jacinto a las orillas del mismo nombre, y acepta la batalla, que le presenta Santa Anna con uno de sus cuerpos de ejército, el día 21 de abril de 1836. Los voluntarios se portan con valor, y señaladamente la caballería mandada por Mirabeau Lamar, distinguido ciudadano de Georgia. El resultado fue la completa derrota del ejército mexicano, de que quedaron 630 muertos, 280 heridos y 730 prisioneros entre ellos el mismo general en Jefe, presidente de la República, o más bien su dictador. Tan señalada victoria sólo costó a los texanos dos muertos y veintitrés heridos, seguro indicante de que más que batalla, fue ésta una sorpresa.

Sólo atento a utilizar la victoria, Houston acoge bajo su protección al ilustre prisionero y lo defiende a duras penas contra la justa saña de sus soldados. Trata con él la evacuación del territorio texano por las dos divisiones aún intactas del ejército invasor, y a este precio le garantiza la vida y la libertad. Ese ejército, que aún se hallaba en disposición de reparar la derrota sufrida y de dar la ley, obedece con singular abnegación las órdenes de su cautivo general, y Houston por su parte, aunque no sin vencer las mayores resistencias, satisface igualmente y da ejecución a sus compromisos. 
Así, el moderno Régulo escapa milagrosamente a la muerte, restituyéndose por la puerta del deshonor a su hogar doméstico, para preparar incansable los medios de rehabilitar su hundida fortuna; y la República de Texas se anuncia al mundo bajo los auspicios de la victoria, como nación independiente.

Las primeras elecciones generales recompensan a Houston con la presidencia de la República que acababa de fundar con su espada, y a Lamar con la vicepresidencia: delante de la gloria del vencedor desaparece en los modestos títulos del patriarca de la colonia texana, Esteban Austin.

En estas elecciones, sobre poco más de 4,000 votos que tomaron parte, 3,277 piden la incorporación a los Estados Unidos; pero este gobierno, que aún no cree llegada la hora, rechaza la tentadora oferta. Hallábase a su frente el intrépido [Andrew] Jackson tocando al término de su segunda presidencia, el mismo que había hecho plantear en México con tan mal suceso la negociación de cesión, el que luego en los momentos críticos había a banderas desplegadas favorecido la insurrección, ya aproximando tropas a las fronteras para alentarla con su presencia, ya haciendo discutir por los puertos en Texas el pabellón americano, a fin de proteger los incesantes envíos de socorro que partían de los de la Unión, e interceptar con cualquier pretexto, como llegó a verificarse, los que pudieran dirigirse al enemigo. Sin embargo, hubo el general demócrata de contentase por lo pronto con el inmenso resultado de la emancipación texana, y de aplazar para más adelante la definitiva determinación de esta grande empresa. El negocio era grave, y a los riesgos interiores se hubiesen añadido complicaciones exteriores de gran monta.

Texas, ofendida pero no desmayada, consagró su atención en la organización interior, a la creación de un ejército, de una marina y de una Hacienda, al desarrollo de la agricultura y del comercio. Continuaron afluyendo a su fértil suelo los emigrados de todas las naciones, desecho de la plebe de la Unión, y también los esclavos y los capitales, que se dedicaron principalmente al cultivo del algodón, artículo con que saldaban el comercio exterior. Claro es, que tal avenida tumultuosa 
de elementos incoherentes, habían de tardar en fundirse en cuerpo ordenado de nación. El agio de las tierras invadió la nueva sociedad como peste desoladora, y mil fraudes, robos y desmanes de gente desalmada, avezada a la licencia más desenfrenada.

A pesar de estos obstáculos prosperaba Texas; pero no tanto que no se abandonase a la confianza y se mirase segura por el lado de México, de donde siempre le amagaba la guerra, considerada allí como nacional por todos los partidos, y por la que se han estado haciendo constantes y duros vejámenes a los pueblos. A esta invasión, siempre inminente, sólo podía seguir oponiendo el mismo entusiasmo entre sus hijos por defender su independencia, mas no aquella fuerza que proviene de un ordenado estado de cosas. Su población blanca, aun cuatro años después de la independencia, no pasaba de 54,000 individuos, gran parte transeúntes; la negra era de 10 a 12,000 y la indígena de 80,000 . Pero ésta, lejos de ser un elemento de fuerza, lo era de debilidad, hallándose en perpetua lucha con ella la población blanca, en una guerra de exterminio, como lo acreditó en la que hizo en 1839 a la tribu poderosa de los cherokíes, que habitaba el Noroeste en los desiertos del interior. La misma población blanca era una turba revuelta de emigrados que no habían podido fijarse en la Unión, y por consiguiente la espuma de los irlandeses, franceses y alemanes, que arrojaba de sí la emigración europea.

El principal renglón del erario lo formaba la venta de las tierras públicas; pero era preciso que la Hacienda se organizase, y que la colonización se fijase y generalizase, para que tomasen valor; entre tanto sólo servían de pábulo a la hoguera del agio, que devoraba aquel suelo virgen. Después venían las aduanas, que en los quince meses anteriores al $1^{\circ}$ de septiembre sólo habían producido 313,196 pesos. Moneda, no se conocía otra que el papel, con los intolerables abusos que de él se hacían en la mayor parte de los estados de la Unión, y que no serían menores en el nuevo de Texas. El ejército después de la guerra de la independencia se encontraba en el mayor desorden, y en vano consagró después a su organización el general Houston sus ciudadanos; sólo consiguió sacrificar su popularidad. La marina con 
muchos mejores elementos, sólo comenzaba a bosquejarse. Su deuda era en 1840 de seis millones de pesos.

Teniendo pues la conciencia de su debilidad, Texas buscaba con empeño un apoyo exterior en que estribar su independencia. Por esto quiso desde luego echarse en brazos de los Estados Unidos, más viéndose desairada, se dio a buscar por Europa el recurso de los empréstitos y de las alianzas. A despecho de las más risueñas pinturas y magníficas promesas, no le fue, empero, posible levantar una empréstito: Europa no creía todavía en la nacionalidad texana, y sólo nuevas complicaciones la determinarian a reconocerla al menos.

Francia se hallaba en 1838 empeñada en una guerra con México, a que la habían conducido relaciones llevadas con altanería por su parte, contestaciones agrias por la de México, y mil desmanes y tropelías de que eran víctimas sus súbditos en la República, donde se había despertado un odio brutal contra los extranjeros, y en especial contra los franceses. Francia que en esta coyuntura se valió de todo género de recursos, que halagó y tendió la mano al partido federal caído para derrocar al central dominante; halló bien cerca un enemigo natural de México, y al punto reconoció la independencia de Texas.

Este paso impremeditado, sugerido por un momento de despecho, se colocó por la imaginación francesa y se vistió con los atavíos de una profunda combinación política, destinada a fomentar la nacionalidad texana y a formar con ella un cordón de colonización francesa, que desde el Seno al Pacífico formase un antemural de la familia latina, y la defendiese contra las invasiones de la sajona. Tan grandiosas esperanzas vinieron a estrellarse en la desavenencia producida por una cuestión, suscitada por la irrupción de unos cerdos en el jardín del enviado francés en Houston. ${ }^{27}$

${ }^{27}$ El encargado de negocios de Francia en Texas fue Alphonse Dubois de Saligny. Vid, Nancy Nichols Barker, "France Disserved: The Dishonourable Career of Dubois de Saligny", Diplomacy in an age of Nationalism, 1971, The Hague, Martinus Nijhoff, p. 25-43. En este artículo la autora narra el chusco incidente al que hace referencia Rivero. La misma historiadora ha traducido y editado cuidadosamente la correspondencia de Dubois de Saligny 


\section{LUIS MANUEL DEL RIVERO}

Siguióse el reconocimiento de Inglaterra, cuyo ojo previsor no alcanzó a ver en la cuestión americana más que una cuestión de mercado para sus manufacturas, hasta que viniéndosele encima la cuestión política, ha pensado, cuando ya no era tiempo, en deshacer su propia obra, la obra de Canning, y en recoger los dispersos restos de la ciudadela que ella contribuyó a derrocar y que sólo pudiera haber resistido el embate furiosos del elemento sajón.

La entente cordiale ${ }^{28}$ fomentó y animó en vano la nacionalidad texana, complaciéndose en prestarle las porciones colosales de un poder rival del de Washington, fundamento del equilibrio americano. Estas pretensiones absurdas, que no impidieron a Texas de continuar sus gestiones para obtener el reconocimiento de México, a quien ofrecía tomar por cinco millones de pesos de su deuda, ni de mendigar en Washington la incorporación, no sirvieron más que a decidir a la democracia americana a apoderarse definitivamente de su presa, no sólo por la conveniencia que en ello tenía, sino por lanzar este desafio a la aristocracia británica. La presidencia de Mr. Polk tuvo esta significación política, y la anexión ha sido el primero y principal acto de su administración.

200 La cuestión del Oregón ha sido por él resuelta en el mismo sentido favorable, aunque no enteramente hostil, sobre la base del paralelo $49^{\circ}$ y libre navegación del [río] Columbia. El pueblo americano, enseñoreado de aquella inmensa región, extiende, sin embargo, su mano codiciosa sobre las Californias, bajo el pretexto de quitárselas a Ingla-

al Ministerio de Negocios Extranjeros de Francia, The French Legation in Texas. Translated and Edited with an Introduction by Nancy Nichols Barker, 1973, Austin, Texas Historical Association. Vid, I, Recognition, rupture and reconciliation.

${ }^{28}$ Sobre la entente cordiale y sus repercusiones en la política española vid, Roger Bullen, "Anglo-French Rivalry and Spanish Politics, 1846-1848", The English Historical Review, v. 89, $\mathrm{n}^{\circ} 350$, enero 1974, Londres, Longman, p. 25-47. El mismo autor tiene un libro sobre la ruptura de dicha entente, vid, Palmerston, Guizot and the collapse of the Entente Cordiale, 1974, Londres, University of London-The Athlone Press. 
terra, que tenía pactada su venta con el presidente Santa Anna, ${ }^{29}$ cuando cayó éste en fin de 1844; ha revolucionado a Nuevo México, y pretende quedársela la condición sine qua non de su paz con México. De Texas quiere hasta el río Bravo, siendo así que jamás se extendió hasta él la provincia antigua, y que sus modernos límites con Coahuila estaban en el río de las Nueces, por la poderosa razón de que el acta de declaración de independencia texana señala aquel límite al nuevo estado. Análogas pretensiones mantiene y hará valer en su día sobre Yucatán. Tal es el progreso de la propaganda americana a la que México sólo puede oponer su derecho, y cuyas usurpaciones se contenta Europa con registrar entre los actos consumados. En nuestro próximo artículo resumiremos y concluiremos.

El Español, 8 de diciembre de 1847.

\section{Artículo XII y último}

A propósito de la fácil ocupación de México por las tropas norteamericanas, y con el fin de poner al público español en disposición de comprender tan extraño desenlace, emprendimos bosquejar un cuadro sucinto de la situación en que dejó España aquel país, vicisitudes por las que ha pasado después, y relaciones que ha sustentado con [su] vecino, los Estados Unidos, hasta el término de verse invadido por éste y sojuzgado. Tres cosas nos parece que resaltan de este imperfecto bosquejo:

$1^{\text {a }}$ Que la dominación española en México se ejerció de una manera justa, benéfica e ilustrada, y si no en mira de los ulteriores destinos de

${ }^{29}$ No sólo Santa Anna pensó en la venta de California a Gran Bretaña. Todavía durante la breve administración de Paredes prevalecieron proyectos similares, pero todos fracasaron. Vid, Carlos Bosch García, Historia de las relaciones entre México y los Estados Unidos (1819-1848), 1961, México, Escuela Nacional de Ciencias Políticas y Sociales, p. 231-3 


\section{LUIS MANUEL DEL RIVERO}

aquella sociedad, al menos con admirable inteligencia de su índole especial y de sus necesidades del momento; no siéndonos imputable el que la violencia de los sucesos nos haya impedido conducirla por entre los escollos de la transformación que hoy nos trabaja a todos, al puerto seguro de una legítima y recíprocamente útil emancipación.

$2^{a}$ Que la revolución inoculada en las venas de aquella sociedad, lejos de vigorizarla, produjo en ella la fiebre, la corrupción de humores y la disolución más espantosa, hasta el punto de convertirla en un cadáver ambulante que ha venido a tierra al menor choque exterior, y ser preciso que sus elementos dispersos se agrupen bajo la presión de un poder extraño aunque sea a expensas de la nacionalidad.

$3^{\text {a }}$ Que la sociedad norteamericana, partiendo del polo opuesto, esto es, del régimen municipal, se encontró después como antes de su justa y gloriosa independencia, funcionando con la plenitud de sus facultades dentro de su natural elemento, el principio democrático; debiendo además a la posesión de un continente virgen y a su posición con respecto a Europa, trabajada a la sazón de tantos males y de una exuberante población, destituida de recursos por los vicios constitutivos de su estado social, el inmenso progreso obtenido en corto espacio de tiempo; pero que cediendo ella a la tentadora ambición de conquistar, se ha derramado por el Nuevo Mundo, no con la majestad de un río caudaloso que fecunda, sino con la fiereza indomable de un torrente que despeña y devasta.

Ahora bien, ¿cuál será la catástrofe de este gran drama, a cuya representación asiste Europa atónita con los brazos cruzados, y de qué manera el desenlace afectará los destinos de América y de la humanidad entera? Y cualquiera que éste sea, ¿podemos nosotros, puede Europa influir en él, nos es dado de meros espectadores pasar a figurar como actores?

A la verdad, no es mi ánimo siquiera intentar la solución de semejantes cuestiones; pretendo solamente sin clavar un ojo temerario en la región velada del porvenir, caminar a pie firme sobre el terreno de los hechos, y llegar hasta donde por él me conduzca mi pobre razón. 


\section{LA GUERRA DE MÉXICO}

Cuando vemos la lucha empeñada entre un gigante y un pigmeo, no es necesario profetizar de quién será el triunfo, pero si la caída del pigmeo no hace más que abrir la verdadera y pesada tarea, entonces la lucha real se restablece con sus contingencias y probabilidades. No dudo que el pueblo norteamericano, está organizado para derramarse por un suelo inmenso, que aguardaba una acción enérgica y fecunda para revelar sus tesoros; pero cualquiera que fuese esa energía, paréceme que bastaba durante siglos a su acción el terreno comprendido entre el Seno y la región de los lagos, entre el Atlántico y el Pacífico; espacio infinito en extensión y en recursos, que contienen el Oregón, el valle del Misisipí, la gran lengua de tierra entre los Apalaches y el Atlántico, y que por sí es ya suntuosa morada, susceptible de recibir con anchura cien millones de habitantes.

El pueblo de los Estados Unidos, sin embargo, no se contenta con la porción que visiblemente le adjudica la Providencia, sino que infatuado por la prosperidad, este escollo terrible de las grandezas humanas, se cree investido de no sé cuál derecho de primogenitura, y no sólo se mira por los indígenas cuya tutela le estaba confiada, sino que aspira a desheredar de su porción legítima hasta a sus mismos hermanos mayores, que cuando menos posee con tan buenos títulos, a los ingleses en el Norte, a los españoles en el Sur, y ya que su audacia se estrelle en la firmeza de los primeros, es bastante dichoso para abrirse paso por entre los términos de los segundos, mientras llega la hora de proclamarse único y universal señor. He aquí el lado flaco de la propaganda norteamericana, el punto vulnerable de la armadura del gigante, porque no es posible sin gastarse luchar aún dichosamente contra la justicia, roca firme ante la cual al fin se estrella hasta la acción de un coloso, ora se llama Alejandro o Napoleón, ora el pueblo de Rómulo o el de Washington.

Si éste comprende sus verdaderos intereses hará bien en poner límites a su ambición, en ceñirse a la tarea que parece haberle confiado la Providencia y que es sobrado grande para colmar sus legítimos restos de gloria y de poder, sin invadir los términos de sus vanos sin hollar sistemáticamente los fueros santos de la humanidad y de la 
justicia, lo cual nunca Dios tolera sin vengarlos, un poco antes o un poco después. Mas por desgracia es aún más fácil conquistarse que dominarse, y la democracia de los Estados Unidos no tiene acostumbrado al mundo al espectáculo de la moderación.

Pero ya que no por estas elevadas consideraciones, conténgase al menos, por otras que más de cerca deben afectarla. El pueblo norteamericano es el menos militar de cuantos nos hablan las historias; él no ambiciona la gloria de las armas, sino el bienestar que dan los escudos, rondar por los bosques con su rifle en busca de caza y de emociones, pero siempre libre, no es ajeno a sus innatas inclinaciones, pero sumirse en unas filas cualesquiera bajo la férula de un cabo o de un general, en donde de su fogosa individualidad no quede más que una unidad que haya de adicionarse o sustraerse de un número, es cosa que resiste por instinto, yugo al cual jamás se encorvará su dura cerviz: los mismos emigrados no van allá para guerrear, sino para enriquecerse. De aquí que contando con 1,800,000 milicianos, a duras penas se encuentran 10,000 hombres para servir en el ejército, y con inmenso trabajo se reunieron hasta 32,000 , aun para rechazar a los odiados ingleses en 1815, y eso que se daban 150 pesos de enganche, y se prometían 150 acres de tierras a la conclusión de la guerra a cada individuo. Así es que este pequeño ejército costó a la República durante dicho año la enorme suma de $29,423,763$ pesos fuertes. Por aquí podrá venirse en conocimiento de las exorbitantes sumas que habrá costado ya a estas fechas la guerra de México hecha a tanta distancia, y en que las tropas pagan al contado [lo que] consumen en el país ocupado.

Esta antipatía de la guerra, unida al enorme gasto con que tiene que hacerse, es lo que principalmente decidió a la democracia americana a moderar sus ímpetus de conquista, el más fuerte argumento de que hoy se prevea de allí el partido de la paz. Añádese la repulsión instintiva de las repúblicas, contra el estado militar, el cual acaba siempre por sojuzgarlas; y la norteamericana que ha eludido dichosamente hasta hoy este terrible escollo, daría indefectiblemente en él, si se obstinase en sus empresas contra las repúblicas hispanoamericanas, las cuales 
LA GUERRA DE MÉXICO

se verían vengadas con exceso el día en que las cadenas que hoy se les remachan a tanto precio, recayesen sobre el cuello de su imprudente vencedor.

Mil otras consideraciones pueden hacerse valer para abogar por esta línea de conducta moderada y sabia, derivadas principalmente del estado interior de la República y de los numerosos gérmenes de división y corrupción que ya abriga en su seno. Ellas han seguramente influido en el ánimo guerreador de Mr. Polk, para solicitar vivamente la paz; pero entonces ¿por qué se aferra en condiciones inconciliables con el honor? ¿Por qué se empeña en humillar hasta el fin a una República en otro tiempo amiga, y hoy por él maltratada, y tan sin razón invadida y despojada? ¿Hay en ella alguna gloria? ¿Hay algún vislumbre de justicia, con que cohonestar siquiera la usurpación escandalosa? ¿Deriva de esto algún honor, provecho alguno, la causa de las instituciones republicanas? ¿Pues que, basta decir: necesito la línea del río Bravo, necesito todo el Nuevo México, ambas dos Californias? El contra-proyecto presentado el 6 [sic] [debe decir 9] de septiembre [de 1847] por el gobierno mexicano a tan gigantescas demandas, ${ }^{30}$ hacía inmensas concesiones a los Estados Unidos, sólo excusables en las angustiosas circunstancias del día, por las que implícitamente cedía la línea del Bravo, y sólo aceptaba el Nuevo México y la Alta California. ¡Caiga, pues, la sangre derramada en tan inicua usurpación sobre los autores y los cómplices de una ambición desmedida! ¡Pueda al menos un anatema de reprobación lanzado por el mundo civilizado, llegar a tiempo de contener a la democracia ameri-

${ }^{30}$ Nótese lo bien informado que estaba Rivero sobre las negociaciones de paz entre México y los Estados Unidos. Vid, "Contraproyecto presentado por los comisionados mexicanos de paz, Sres. Gral. José Joaquín Herrera, Lic. José Bernardo Couto, Gral. Ignacio Mora y Villamil y Lic. Miguel Atristáin, en la junta del día 9 de septiembre de 1847", apud, Documentos anexos a la $1^{\mathrm{a}}$ edición en castellano del Diario del presidente Polk. Numerosos documentos anexos relacionados con la guerra entre México y los Estados Unidos. Recop., trad., pról. y notas de Luis Cabrera, 1948, México, Antigua Librería Robredo. 
cana, en la rápida pendiente de ruina por la que se va precipitando! ¡Pueda el espíritu de moderación volver a sus consejos, y un respeto inviolable de la justicia ligar sus manos para hacer la iniquidad, y desatarlas para entregarse toda entera a la obra providencial de descuajar un continente virgen y de preparar un asilo de virtud y de paz a la humanidad desterrada y perseguida en los demás puntos del globo!

¿Y qué puede hacer en esto Europa? Su acción sobre América en lo que va de este siglo, lleva el sello de un egoísmo imprevisor. Un resto, ya absurdo, de aquella prevención y envidia que excitó en otro tiempo la fortuna de España, la ha llevado hoy a favorecer la emancipación de nuestras colonias, y a acogerla con alborozo una vez realizada, por ver con ella a un tiempo consumada nuestra humillación y abiertos los codiciados puertos del Nuevo Mundo a su especulación. No parece sino que sea éste el siglo de los mercaderes, porque no hay consideración ni argumento que no se sacrifique a un interés cualquiera comercial; pero es lo peor que esa política mercantil después de hacer gemir por doquiera a la humanidad, resuelta las más [de las] veces, que ni aun sus inmediatos intereses ha alcanzado a divisar. Así es, que espantada ante su propia obra, ha intentado Europa retrogradar, y poniéndose a remolque de Inglaterra que aquí, como en otros muchos puntos del globo, no persigue sino un mercado más para sus manufacturas, ha ideado, en busca del equilibrio americano, de cuya falta acaba de apercibirse, primero, contraponer Texas a los Estados Unidos, luego, apoderarse de las Californias y aún ocupar el Oregón, y por último, saliéndole fallidos sus cálculos, y cada vez más engrosado el poder norteamericano, ha predicado la monarquía en México bajo un príncipe Borbón. ${ }^{31}$

Pero era preciso haber tenido en cuenta, que nada hay más propio para irritar al pueblo de los Estados Unidos, y para obligarle a soltar

${ }^{31}$ En los últimos años sobre este tema han salido a la luz dos investigaciones: Miguel Soto, La conspiración monárquica en México, 1845-1846, 1987, México, EOSA. Este libro a mi juicio es el mejor. Contamos también con una versión cuidada en el fondo, pero muy discutible en sus interpretaciones de 
la brida de su ambición, que el conato de intervención europea en los negocios interiores de América, mucho más cuando esa intervención se anuncia bajo la bandera de la monarquía, y mucho más aún cuando en el fondo de todos estos proyectos descubre la mano de la aristocracia británica, su natural enemigo, con la que tendrá en fin que romper lanzas más tarde o más temprano. Si realmente tenéis la voluntad firme y enérgica de intervenir en América para impedir que se os escape de las manos, y para que continúe atado al carro del Viejo Mundo, hacedlo en buen hora; la empresa merece un sacrificio. Pero si desde las Cruzadas acá no ha sido posible reunir la Europa dentro de un solo campamento, si hoy más que nunca se halla dividida y harto despedazada, si vuestra intervención había de ser poco más que diplomática, y sólo había de producir el efecto de irritar al león, entonces renunciad siquiera por humanidad a vuestros quiméricos proyectos, a menos que abriguéis el maquiavélico de forzar al enemigo a cometer faltas, y a debilitarse por sus propias exageraciones.

No sólo aborrece el pueblo norteamericano esta intervención europea, sino también el mismo pueblo mexicano, con excepción del clero y una que otra clase. Aborrecióse allí a los ingleses y singularmente a los franceses, y en general a todo extranjero, en cuyo odio nos cabe a nosotros una parte, si bien la más pequeña, porque han llegado a persuadirse que entre todo, los que llevan miras más desinteresadas y más en armonía con el bien general del país son los españoles como particulares y como gobierno. Así que, el medio mas seguro de volvernos a hacer odiosos, sería el de presentarnos allí con la pretensión de regeneradores monárquicos, y unida la Europa en este común pensamiento, aún quedaría un trabajo infinito para hacérselo aceptar a los mismos que por él habían de ser beneficiados.

Jaime Delgado, La monarquia en México (1845-1846), 1989, México, Porrúa. De ambas investigaciones se deduce que el papel de la diplomacia británica fue la de espectadora, interesada desde luego en la marcha del proyecto, pero que nunca tomó parte activa en el mismo. 


\section{LUIS MANUEL DEL RIVERO}

España tiene también otros intereses sagrados por que velar, conserva de su pasada opulencia residuos bastantes para ennoblecer y enriquecer un imperio; mantiene preciosas colonias que hacen su orgullo, por cuya seguridad y prosperidad debe trabajar, y que comprometería el día en que se lanzase en esa política militante en que ha estado a pique de entrar. ¡Quiera el cielo que aun observando estricta neutralidad, a fuerza de solicitud y de prudencia, conserve algún tiempo esos codiciados establecimientos! Los destinos del Nuevo Mundo por otra parte, no gravitan ya sobre nuestros hombros: la Providencia nos ha librado de esta carga que llevamos con tanto honor y la ingratitud de nuestros hijos nos ha revelado de toda obligación especial respecto de ellos.

¿Perecerá, pues la noble nacionalidad española en aquel continente por ella misma descubierto y fecundado? éste es el secreto y la Providencia, que no permitirá, esperémoslo así, que desaparezca el fruto de tanto celo y trabajo apostólicos de tanta virtud y sabiduría práctica.

Pero en cuanto a los mexicanos, deben tomar su partido, y esperar sólo de sí y de Dios el remedio. Luchar contra el coloso sería empeñarse en una guerra de exterminio: fáltanles los recursos de todo género, y en sus pechos arde la llama que a nuestros padres impelió contra la huestes de Napoleón ¿Qué medio pues? Transigir, decidirse a hacer los más grandes sacrificios no sólo de territorio, sino hasta nacionalidad para poder vivir en paz con tan terrible vecino, aguardando mejores días.

Efectivamente después de una derrota tal y de un tan profundo abatimiento, los hombres pensadores de aquel país deben haber adquirido la convicción de que la antigua nacionalidad no puede ya por sí levantarse ni levantar a la sociedad postrada con ella en tierra, y que es preciso que esa sociedad se regenere bajo los auspicios de un nuevo principio, el principio democrático, al cual se le abran de par en calle las avenidas de la inmigración hasta hoy cerradas, entre otras causas, por la influencia de la Iglesia que ha prohibido la libertad de conciencia; es preciso que la acción de ese principio se vea libre del contacto militar que tanto la ha perjudicado, suprimiéndose ese ejército que tantos daños ha causado y nada bueno ha hecho; que en fin, para 
ayudar a ese principio a formar una nueva sociedad, porque de nada menos hay que tratar, no sólo reciba la protección que ha menester contra sus numerosos enemigos, sino que se le preserve de las aberraciones y excesos en que daría, abandonando a sí propio, encargándose este protectorado y tutela a la prudencia del vencedor. Así no se habrá salvado todo, pero se habrá salvado lo posible, y el país se regenerará.

El Español, 9 de diciembre de 1847. 